\title{
Clouds over Hyytiälä, Finland: an algorithm to classify clouds based on solar radiation and cloud base height measurements
}

\author{
Ilona Ylivinkka ${ }^{1,2}$, Santeri Kaupinmäki ${ }^{1, a}$, Meri Virman ${ }^{1}$, Maija Peltola ${ }^{1}$, Ditte Taipale ${ }^{1,2}$, Tuukka Petäjä ${ }^{1}$, \\ Veli-Matti Kerminen ${ }^{1}$, Markku Kulmala ${ }^{1}$, and Ekaterina Ezhova ${ }^{1}$ \\ ${ }^{1}$ Institute for Atmospheric and Earth System Research/Physics, Faculty of Science, \\ University of Helsinki, P.O. Box 64, 00014 Helsinki, Finland \\ ${ }^{2}$ SMEAR II station, University of Helsinki, 35500 Korkeakoski, Finland \\ ${ }^{a}$ current address: Department of Medical Physics and Biomedical Engineering, \\ University College London, London WC1E 6BT, United Kingdom
}

Correspondence: Ilona Ylivinkka (ilona.ylivinkka@helsinki.fi)

Received: 3 April 2020 - Discussion started: 8 June 2020

Revised: 1 September 2020 - Accepted: 11 September 2020 - Published: 22 October 2020

\begin{abstract}
We developed a simple algorithm to classify clouds based on global radiation and cloud base height measured by pyranometer and ceilometer, respectively. We separated clouds into seven different classes (stratus, stratocumulus, cumulus, nimbostratus, altocumulus + altostratus, cirrus + cirrocumulus + cirrostratus and clear sky + cirrus $)$. We also included classes for cumulus and cirrus clouds causing global radiation enhancement, and we classified multilayered clouds, when captured by the ceilometer, based on their height and characteristics (transmittance, patchiness and uniformity). The overall performance of the algorithm was nearly $70 \%$ when compared with classification by an observer using total-sky images. The performance was best for clouds having well-distinguishable effects on solar radiation: nimbostratus clouds were classified correctly in $100 \%$ of the cases. The worst performance corresponds to cirriform clouds (50\%). Although the overall performance of the algorithm was good, it is likely to miss the occurrences of high and multilayered clouds. This is due to the technical limits of the instrumentation: the vertical detection range of the ceilometer and occultation of the laser pulse by the lowest cloud layer.

We examined the use of clearness index, which is defined as a ratio between measured global radiation and modeled radiation at the top of the atmosphere, as an indicator of clear-sky conditions. Our results show that cumulus, altocumulus, altostratus and cirriform clouds can be present when the index indicates clear-sky conditions. Those conditions
\end{abstract}

have previously been associated with enhanced aerosol formation under clear skies. This is an important finding especially in the case of low clouds coupled to the surface, which can influence aerosol population via aerosol-cloud interactions. Overall, caution is required when the clearness index is used in the analysis of processes affected by partitioning of radiation by clouds.

\section{Introduction}

Clouds regulate the radiative heating of the Earth, because they reflect a large share of the incoming solar radiation back to space and also absorb and re-emit long-wave radiation radiated by the Earth (Schneider and Dennett, 1975; IPCC, 2013). The light scattering and absorption properties of clouds depend on their thickness and spatial distribution but also on the size and phase of cloud droplets. These characteristics, in turn, vary for different types of clouds. For example, optically thick stratiform clouds effectively decrease the amount of solar radiation reaching the surface of the Earth and thereby cooling the climate. The dominant impact of optically thin and transparent cirrus clouds is mainly on the outgoing long-wave radiation, leading to a net warming effect (IPCC, 2013). Additionally, clouds alter the ratio between direct and diffuse radiation on the surface of the Earth (Kasten and Czeplak, 1980; Calbó et al., 2001). Hence, the cloud properties largely affect the radiation budget of the 
Earth (Sinha and Shine, 1995; Loeb et al., 2009) as well as many physical and chemical processes in the planetary boundary layer (Gu et al., 1999; Mogensen et al., 2015; Jokinen et al., 2017). Many of the cloud-related interactions and feedbacks are not well understood, causing large uncertainties in the predictions of future climate change (IPCC, 2013).

Short-wave global radiation comprises direct radiation coming from the direction of the Sun and diffuse radiation coming from all other directions due to scattering of solar radiation in the atmosphere. Under clear-sky conditions, $10 \%-$ $20 \%$ of global radiation is diffuse radiation, depending on the aerosol load in the atmosphere and time of the day. When clouds overcast the sky, diffuse radiation is nearly equal to global radiation (Page, 2012). An additional effect related to partitioning of solar radiation by clouds is global radiation enhancement (GRE), which means that the measured global radiation exceeds the theoretical maximum clear-sky radiation and is associated with specific "focusing" of radiation by clouds (Pecenak et al., 2016).

Partitioning of radiation by clouds affects on ecosystem and atmospheric processes. For example, under diffuse radiation conditions, the photosynthesis of a forest ecosystem is more effective. Such enhancement is presumably caused by the facts that diffuse radiation penetrates more evenly inside the canopy so that a larger number of leaves can photosynthesize efficiently and that photosynthetic saturation of the leaves on top of the canopy is less likely to be reached (Gu et al., 2002; Kivalov, 2018). In cloudy conditions, the increase in gross primary production, which is a measure of ecosystem-scale photosynthesis, can be up to $30 \%$ compared to clear-sky and clean-atmosphere conditions in boreal forests (Ezhova et al., 2018).

The presence of clouds also modulates atmospheric chemistry. For example, the production of $\mathrm{OH}$, which is the most important oxidant in the atmosphere, is reduced when clouds limit the incoming ultraviolet radiation and thereby also reducing the oxidation of, for example, biogenic volatile organic compounds (BVOCs) (Atkinson and Arey, 2003; Mogensen et al., 2011, 2015; Hellén et al., 2018). Oxidized BVOCs form vapors that are able to contribute to the formation and growth of atmospheric aerosol particles (Hallquist et al., 2009; Riipinen et al., 2012; Donahue et al., 2013; Schobesberger et al., 2013; Ehn et al., 2014; Kulmala et al., 2014b; Riccobono et al., 2014). The changes in aerosol processes additionally affect cloud condensation nuclei (CCN) production in the atmosphere (Kerminen et al., 2012; Paasonen et al., 2013; Scott et al., 2018; Sporre et al., 2019), altering also several cloud properties, such as their albedo and lifetime, their ability to precipitate, and cloudiness in a more general sense (Twomey, 1977; Albrecht, 1989; Gryspeerdt et al., 2014; Rosenfeld et al., 2014). Hence, the modulations in cloudiness affect a variety of different simultaneous processes and feedbacks, and the research on these interactions requires accurate knowledge of different cloud types and their effects on radiation on different timescales (Hussein et al., 2009; Rannik et al., 2013; Dada et al., 2018; Ezhova et al., 2018).

Traditionally, cloud-type classification has been based on human observations. However, human observations are not always available, especially in remote locations, and the time resolution of the data is too low for many scientific applications. Thus, automated cloud classification methods have been developed. Data from either ground or satellite instrumentation can be used for the classification. The equipment for this purpose include cameras, radiosondes, different kinds of irradiance meters and radars (Tapakis and Charalambides, 2013). The classification applied in simple models can be based on only one instrument (Duchon and O'Malley, 1999), or the algorithm can employ data from several instruments (Wang and Sassen, 2001). Ground-based measurements provide accurate results on local variations in cloudiness, whereas satellite measurements cover large-scale phenomena (Duchon and O'Malley, 1999; Ricciardelli et al., 2008).

In instrument-based cloud classification, the clouds can be classified according to, for example, the attenuation of irradiance compared to theoretical clear-sky values or meteorological variables, such as temperature thresholds. Imagebased classification employs spectral and textural features of an image. For example, the tonal variation may help with distinguishing between different types of clouds (e.g., cirrus and cumulus), and the spatial homogeneity allows us to discriminate between similar types of clouds (e.g., cumulus and stratocumulus) (Haralick et al., 1973; Calbó and Sabburg, 2008; Heinle et al., 2010). The algorithms calculating the cloud occurrence can be either very simple, only separating clouds from the background (Cayula and Cornillon, 1996; Long and Ackerman, 2000; Mukherjee and Acton, 2002), or sophisticated, classifying different cloud types into several classes (Calbó et al., 2001; Bankert and Wade, 2007; Ricciardelli et al., 2008). The classification can be based on exceeding linear threshold values (Kegelmeyer, 1994), or it can apply machine learning and artificial intelligence with large training sets (Bankert and Wade, 2007; Mazzoni et al., 2007).

The selection of a suitable method depends on the application of the results. For example, Cloudnet measurement stations, producing cloudiness data for the needs of weather forecasting, have at least three instruments providing information on cloud vertical structure and ice and liquid water contents (Illingworth et al., 2007). The main instruments include Doppler cloud radar, ceilometer and dualfrequency microwave radiometer. The calibration and data handling processes are exact and prearranged (Illingworth et al., 2007). While, overall, Cloudnet provides very detailed information on clouds, for some applications this information is redundant. As an example, when dealing with the processes related to solar radiation, it is reasonable to characterize clouds using solar radiation as a classification parameter. Moreover, Cloudnet stations and the instruments they use 
are rare, while, for example, global radiation and cloud base height $(\mathrm{CBH})$ are often measured routinely.

Measurements at SMEAR II (Station for Measuring Ecosystem-Atmosphere Relations) in Hyytiälä, Finland, aim for comprehensive understanding of the ongoing processes in the atmosphere, ecosystem and the interactions between them (Hari and Kulmala, 2005). Despite the importance of the clouds on these processes, to date the prevailing cloud types have not been identified. Therefore, the objective of this work is to formulate a simple and inexpensive method to estimate cloud types over SMEAR II, employing its existing instruments.

Our automatic cloud classification algorithm is based on global radiation and $\mathrm{CBH}$ measurements. It is an adaptation of the work by Duchon and O'Malley (1999). Their so called "pyranometer method", using only pyranometer data, was developed to classify clouds in places where no human observations were available. Even though the pyranometer method is simple and effective, its cloud-type classes are rather broad (stratus, cumulus, cumulus + cirrus, cirrus, clear sky, precipitation + fog and other), and the classification was found to be in agreement with human observations only $45 \%$ of the time. Our improved cloud-type classification algorithm additionally uses $\mathrm{CBH}$ data. Hence, the number of cloud-type classes can be increased compared to Duchon and O'Malley (1999), because the clouds at different levels can be distinguished. Cloud classes in our algorithm are cumulus, stratus, stratocumulus, nimbostratus, altocumulus + altostratus, cirrus + cirrocumulus + cirrostratus, clear + cirrus, cumulus + GRE and cirrus + GRE. Although the algorithm is developed using the data from one measurement station, it can also be applied to other environments.

In order to illustrate the application of the new cloud classification algorithm, we study the cloud statistics over Hyytiälä. In the future, the results of this algorithm may be employed in other analyses regarding cloud-related interactions and feedbacks. This is possible due to the fact that the data set including ceilometer and pyranometer data from SMEAR II is more than 10 years long, which is considerably longer than many more advanced cloudiness measurements with only few years long data set (e.g., Cloudnet having totalsky imagery from Hyytiälä for less than 1 year).

\section{Materials and methods}

We developed a cloud classification algorithm, utilizing global radiation and $\mathrm{CBH}$ data, to identify cloud types and analyze the statistics pertaining to cloudiness. In Sect. 2.1 we first introduce the measurement site, instruments and data set. The radiation-based parameters employed for the cloud classification are derived in Sect. 2.2, and in Sect. 2.3 we describe how cloud occurrence can be estimated. Finally in Sect. 2.4, we introduce cloud optical depth (COD), which is later used for examining how well our parameter and mea- sured COD values are connected and follow the theoretical relation.

\subsection{Site and data set}

SMEAR II in Hyytiälä in southern Finland $\left(61^{\circ} 51^{\prime} \mathrm{N}\right.$, $24^{\circ} 17^{\prime} \mathrm{E}, 181 \mathrm{ma.s.1}$ ) is a background measurement site. The state of the atmosphere and ecosystem are monitored with various instruments to understand the ongoing processes, interactions and feedbacks. The station was established in 1995, and it is surrounded by a forest dominated by Scots pine (Pinus sylvestris) with a canopy height of ca. $18 \mathrm{~m}$ (Hari and Kulmala, 2005).

The main data set in this work includes data from a pyranometer and a ceilometer. The pyranometer (Middleton solar SK08 pyranometer) measures global radiation at wavelengths of $0.3-4.8 \mu \mathrm{m}$. The measurements were conducted above the canopy level at SMEAR II. The ceilometer (Vaisala CL31) detects CBHs for a maximum of three different cloud layers based on the back-scattering profile of a laser pulse. Its maximum measurement height is $7500 \mathrm{~m}$. Data points with full and partial obscuration, occurring usually during rain or fog events, have been excluded from the analysis.

The measured global radiation $\left(I_{\text {meas }}\right)$ was compared to modeled clear-sky radiation $\left(I_{\mathrm{gh}}\right)$ to quantify how effectively clouds block radiation. To calculate the modeled clear-sky radiation, we used the Solis clear-sky model (Ineichen, 2008). The model is different from that of Duchon and O'Malley (1999), in which precipitable water (PW) was estimated based on dew point and aerosol optical depth (AOD) was taken to be constant. We used the Solis model because it explicitly takes into account the aerosol load in the atmosphere. However, in case AOD and precipitable water data are not available when applying this algorithm in other environments, other clear-sky models may be employed, though we recommend to use a model that is as accurate as possible.

The input parameters for the Solis model are measured AOD at $700 \mathrm{~nm}$ and precipitable water. We used AOD at $675 \mathrm{~nm}$ and precipitable water obtained from the AErosol RObotic NETwork (AERONET) database for Hyytiälä (Holben et al., 1998). Note, however, that the data from 2014 can be found under the name "ARM Hyytiälä Finland", because in 2014 the Atmospheric Radiation Measurement (ARM) facility of the U.S. Department of Energy had a campaign called "Biogenic Aerosols - Effects on Cloud and Climate" (BAECC) in Hyytiälä (Petäjä et al., 2016). We used version 2 and level 2 (cloud screened and quality controlled) AERONET data. The data are available at https://aeronet.gsfc.nasa.gov/cgi-bin/webtool_opera_ v2_new?stage $=3 \&$ region $=$ Europe $\&$ state $=$ Finland $\&$ site $=$ Hyytiala\&place_code=10 (last access: 21 October 2020).

In the development and validation process of the algorithm, we employed cloud classification made by human observer based on total-sky images taken during the BAECC campaign between 1 May and 31 July 2014 (Fig. 1). In the 


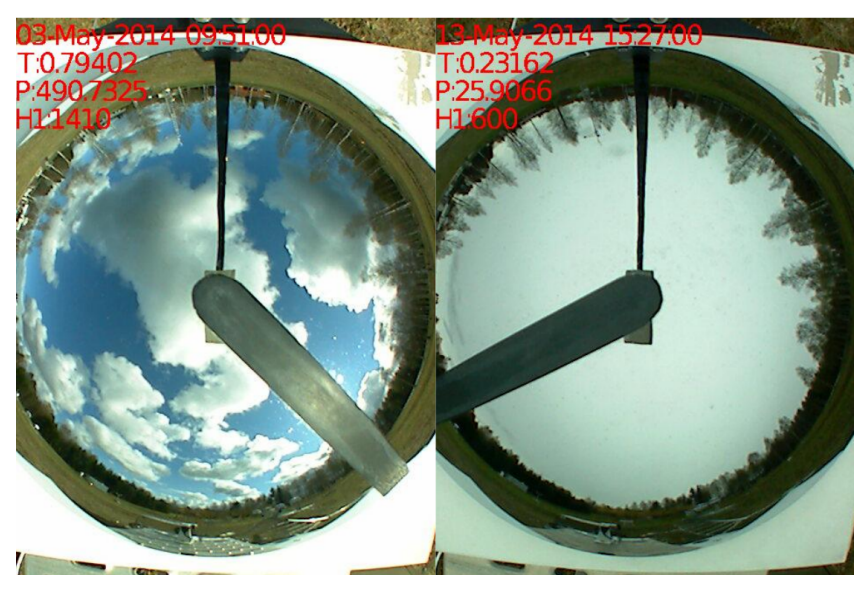

Figure 1. An example of total-sky images taken in Hyytiälä that were used when formulating the algorithm. Transmittance, patchiness and the lowest $\mathrm{CBH}$ are marked in the figures. Figure courtesy of ARM.

validation process, we used ceilometer data from the BAECC campaign. The ceilometer used in the campaign was also a Vaisala CL31, but it was positioned about $500 \mathrm{~m}$ away from the standard ceilometer of SMEAR II. We discuss the consequences of ceilometer position for cloud classification in Appendix A1 (Fig. A1).

In the cloudiness and cloud classification analysis, we used quality-checked pyranometer and ceilometer data, measured at SMEAR II in 2014 and 2016-2017. Data from 2015 were excluded because the data availability was low due to instrumental issues of the ceilometer. The time resolution of the data was $1 \mathrm{~min}$, and gaps were interpolated with the nearest value. The interpolation was important only for intermittent measurements of precipitable water and AOD. Moreover, due to their low availability in March, April and September, we calculated the median values of the available data, and we employed them when the data were missing in those months. Here we calculated median values separately for MarchApril and September. The gained values for springtime were $\mathrm{AOD}_{\mathrm{MA}}=0.0252$ and $\mathrm{PW}_{\mathrm{MA}}=0.4731 \mathrm{~cm}$, and for September they were $\mathrm{AOD}_{\mathrm{S}}=0.0872$ and $\mathrm{PW}_{\mathrm{S}}=1.1970 \mathrm{~cm}$. Otherwise the data availabilities of the measured variables were high during the measurement period (ca. 90\%). When conducting seasonal analysis, we determined the seasons so that spring included March, April and May, followed by summer (June, July and August), autumn (September, October and November) and winter (December, January and February).

For the cloud-type classification and cloud occurrence analysis based on pyranometer measurements, we used only data when solar zenith angle (SZA) was less than $70^{\circ}$ as the pyranometer data are not reliable when the Sun is close to horizon. Because SZA is always larger than $70^{\circ}$ before 27 February and after 16 October, we included only data from March to September so that we used only months with full data availability. However, for the cloud occurrence and $\mathrm{CBH}$ analysis using the ceilometer measurements, we used data independent of the time of day and season, because unlike the pyranometer, the ceilometer is not sensitive to SZA. We calculated the value of SZA with the Solar Position Algorithm (SPA) online calculator, available at https://midcdmz.nrel.gov/solpos/spa.html (last access: 9 January 2020).

\subsection{Cloud-type classification parameters}

Our algorithm uses three parameters to classify clouds: transmittance (TR), patchiness (PA) and measured CBH. Transmittance is the ratio of the measured global radiation $\left(I_{\text {meas }}\right)$ to the modeled clear-sky radiation $\left(I_{\mathrm{gh}}\right)$, given by Eq. (5), averaged over a running time interval:

$$
\begin{aligned}
\mathrm{TR} & =\left\langle\frac{\text { measured global radiation }}{\text { modeled clear-sky radiation }}\right\rangle_{21 \mathrm{~min}} \\
& =\left\langle\frac{I_{\mathrm{meas}}}{I_{\mathrm{gh}}}\right\rangle_{21 \mathrm{~min}} \cdot
\end{aligned}
$$

Transmittance describes how effectively clouds block solar radiation. It is equal to 1 in clear-sky conditions and approaches 0 for an overcast sky.

The chosen time interval in this work was $21 \mathrm{~min}$, similar to Duchon and O'Malley (1999) to be able the compare our results. However, the length of the time interval is based on empirical experience of the time span of cloud variability in the sky and the lifetime of clouds. Cumulus clouds are the largest patchy clouds; hence, they are used as a reference for the time span of clouds. The representative size of typical cumulus clouds is $1 \mathrm{~km}$, and if assuming that the average wind speed is about $3-6 \mathrm{~ms}^{-1}$ (Stull, 2000), then during $21 \mathrm{~min}$ the clouds can move $3.8-7.6 \mathrm{~km}$, meaning that roughly four to eight clouds can pass the measurement beam of the instruments. Capturing several clouds is necessary for the calculation of standard deviation, which is employed when calculating patchiness as described below. Hence, decreasing the 21 min time interval can be problematic due to an insufficient number of passing clouds needed for the calculation. Moreover, a study by Rodts et al. (2003) showed that ca. $1 \mathrm{~km}$ sized clouds dominate the vertical mass and buoyancy fluxes. Thus, they can be expected to be optically thicker than smaller or larger clouds; thereby, they cause the largest decrease in solar radiation which contributes to the standard deviation the most. Rodts et al. (2003) also showed that the cloud cover density is dominated by intermediate clouds with linear sizes of $0.7-1 \mathrm{~km}$. This means that they give the largest contribution to the cloud cover, determined as a ratio of the $2 \mathrm{D}$ projection of the area occupied by clouds to the total image area. Another time constraint is related to the lifetime of clouds. A typical lifetime of cumulus cloud is $20 \mathrm{~min}$, so $21 \mathrm{~min}$ is reasonable to capture one life cycle of cumulus clouds (Lohmann et al., 2016). Other clouds have longer lifetimes (Lohmann et al., 2016). Therefore, we can expect 
that 20-30 min would give the same results, but considerably shorter time intervals would not give the best representation of the overall cloudiness conditions and a longer time interval would increase the number of poorly defined cases when there is a transition from one type of cloudiness to another.

Patchiness is the running standard deviation $(\sigma)$ of scaled, measured global radiation $\left(I_{\mathrm{sc}, \text { meas }}\right)$ :

$$
\begin{aligned}
\mathrm{PA} & =\sigma\left(\frac{\text { measured global radiation } \times 1400 \mathrm{~W} \mathrm{~m}^{-2}}{\text { modeled clear-sky radiation }}\right)_{21 \mathrm{~min}} \\
& =\sigma\left(I_{\mathrm{sc}, \text { meas }}\right)_{21 \mathrm{~min}} .
\end{aligned}
$$

The modeled clear-sky radiation is calculated using Eq. (5). Patchiness determines the variability of the cloud layer. The value is lowest for both uniformly overcast and clear-sky conditions and increases in partly cloudy conditions. The same time interval of 21 min was used.

The relationship between the measured global radiation and the modeled global radiation gives the fraction of radiation that reaches the surface of the Earth. We scaled the measured radiation because the magnitude of the oscillations in the radiation due to clouds are different depending on the time of day. Since the amount of incoming solar radiation is lower in the morning and evening compared to noon, the fluctuations due to same types of clouds are higher around noon. We used $1400 \mathrm{~W} \mathrm{~m}^{-2}$ for scaling because it is slightly higher than the theoretical maximum of incoming solar radiation. The scaling factor $(s)$ was calculated as in Duchon and O'Malley (1999):

$s=\frac{1400 \mathrm{~W} \mathrm{~m}^{-2}}{I_{\mathrm{gh}}}$.

We multiplied the measured global radiation by the scaling factor in order to obtain the scaled radiation:

$I_{\mathrm{sc}, \text { meas }}=I_{\text {meas }} \cdot s$.

The third parameter of our algorithm is the running minimum of the lowest CBH over a 21 min time interval.

In this study, we used the Solis clear-sky model to calculate the amount of global radiation that would reach the surface of the Earth in the case when there were no clouds (Ineichen, 2008). From the model, the obtained global radiation at ground level is

$I_{\mathrm{gh}}=I_{0}^{\prime} \cdot \exp \left(\frac{-\tau_{\mathrm{g}}}{\cos ^{g}(\mathrm{SZA})}\right) \cdot \cos (\mathrm{SZA})$,

where $I_{0}^{\prime}$ is the solar flux density at the top of the atmosphere $\left(I_{0}\right)$ multiplied by a factor associated with AOD and precipitable water, $\tau_{\mathrm{g}}$ is global total optical depth, and $g$ is a fitting parameter related to AOD and precipitable water. The detailed descriptions of the parameters can be found in Ineichen (2008).

\subsection{Cloud occurrence}

We analyzed the cloud occurrence in Hyytiälä based on the ceilometer and pyranometer measurements. From the ceilometer data, the cloud occurrence is simply the number of cases when the ceilometer detected a cloud base. From the pyranometer data, the clear-sky or cloudy conditions can be estimated using a clearness index $(C)$. It is determined as a relation between the measured global irradiance and modeled irradiance on a horizontal surface at the top of the atmosphere:

$C=\frac{I_{\text {meas }}}{I}$.

The irradiance at the top of the atmosphere can be calculated as

$I=\cos (\mathrm{SZA}) \cdot I_{0}$.

When the radiation measured with the pyranometer was less than a certain percentage of the modeled top-ofatmosphere radiation, we assumed that the data point corresponded to cloudy conditions. For summer months, the percentage that we used was $70 \%$; for April it was $65 \%$, and for March and September it was $55 \%$. We estimated the percentages separately for each month using a clear-sky model with relatively high aerosol load $\left(\mathrm{AOD}_{675 \mathrm{~nm}}=0.17\right)$. The percentages were different for different months because the position of the Sun is higher in summer than in spring and autumn. We used a $21 \mathrm{~min}$ running average of the pyranometer data in $1 \mathrm{~min}$ time resolution. Only data from March to September were used to avoid errors in the measurements caused by large SZA.

\subsection{Transmittance and cloud optical depth}

For a homogeneous, nonpatchy cloud, the connection between transmittance and COD is described by the following theoretical formula (Bohren, 1987; Sena et al., 2016):

$\mathrm{TR}=\frac{2}{2+\frac{(1-a) \mathrm{COD}}{\cos (\mathrm{SZA})},}$

where $a$ is a asymmetry parameter of the cloud droplets. Note that in Sena et al. (2016) there is an extra cosine term in the numerator of the formula, which we removed. In the limiting case of $\mathrm{COD}=0$, the extra cosine term leads to an incorrect result of $\mathrm{TR}=\cos (\mathrm{SZA})$ instead of $\mathrm{TR}=1$.

In Hyytiälä, COD has been measured between 17 July and 31 August 2014 during the BAECC campaign with a threewaveband spectrally agile technique (TWST) sensor (Niple and Scott, 2016). To estimate how well our transmittance parameter (calculated with Eq. 1), and the measured COD follow the theory, we calculated theoretical transmittance values using Eq. (8) for several SZAs, and we compared those with the measured values. We assumed that in Eq. (8) $a=0.86$, which is similar to Sena et al. (2016). 


\section{Results and discussion}

First, the cloud classification algorithm is introduced along with the evaluation of the performance of the algorithm (Sect. 3.1). Second, we analyze the ceilometer and the pyranometer data to study the seasonal variation in cloud occurrence in order to gain insight into how often clouds are observed over Hyytiälä and what are the typical CBHs (Sect. 3.2). We study the statistics of the automatically produced cloud types in Sect. 3.3. In Sect. 3.4, we briefly discuss the further applications and developments of the algorithm, including the use of clearness index as an indicator of clear-sky conditions and the possibility to estimate COD using transmittance; finally, in Sect. 3.5 we compare the main findings of this work with other studies.

\subsection{New cloud classification algorithm and its evaluation}

The algorithm classifies clouds based on three parameters, determined in Sect. 2.2: transmittance, patchiness and CBH. Based on total-sky images from Hyytiälä (Fig. 1), we adjusted the ranges of the parameters, corresponding to different types of clouds, by constructing planes of parameters (TR, PA) separately for each cloud type. We took a sample of 665 total-sky image-measurement data pairs randomly yet uniformly in time, i.e., making sure that we utilized the whole measurement period from among a set of total-sky images taken between 1 May and 31 July 2014 in Hyytiälä. To ensure that the middle- and high-level clouds were represented in the analysis, we took another sample of 320 pairs with the condition that the minimum $\mathrm{CBH}$ at that time was at least $2000 \mathrm{~m}$.

We first visually classified the clouds into cumulus, stratus, stratocumulus, nimbostratus, altocumulus, altostratus, cirrus, cirrocumulus, cirrostratus or clear sky, and the corresponding transmittance, patchiness and $\mathrm{CBH}$ were recorded. We put the transmittance and patchiness values in the plane of parameters (TR, PA) in order to determine the regions in the plane, corresponding to different cloud types. Some cloud types had significant overlapping in the plane of parameters (TR, PA) and thus could not be distinguished from each other from the point of view of their influence on solar radiation. Those we combined into more general cloud classes (altocumulus and altostratus, cirrus, cirrocumulus and cirrostratus, and clear sky and cirrus). The clear-sky class also contains cirrus clouds, because cirrus clouds are difficult to distinguish from clear sky as they have high transmittance and may have undetected CBH. Hence, the final cloud classes used in this study are cumulus $(\mathrm{Cu})$, stratus (St), stratocumulus ( $\mathrm{Sc}$ ), nimbostratus (Ns), altocumulus + altostratus $(\mathrm{Ac}+\mathrm{As})$, cirrus + cirrocumulus + cirrostratus $(\mathrm{Ci}+\mathrm{Cc}+\mathrm{Cs})$ and clear + cirrus $($ clear $+\mathrm{Ci})$. Additionally, we defined separate classes for cumulus and cirrus clouds that caused global

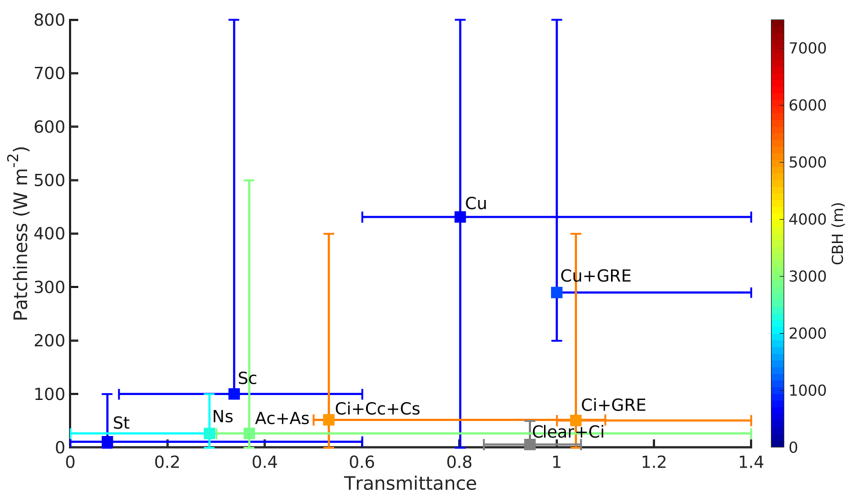

Figure 2. Illustration of the transmittance and patchiness ranges used as classification criteria for different cloud types. Markers display the locations of the maximum data point density of each cloud type, and whiskers extend to the lower and upper limits of the permitted parameter ranges (also listed in Table 1). Color shows the average $\mathrm{CBH}$ of each cloud type.

radiation enhancement $(\mathrm{Cu}+\mathrm{GRE}$ and $\mathrm{Ci}+\mathrm{GRE}$, respectively).

We created rectangular segmentations in the TR, PA plane based on those cloud classes and thus gained the new parameter ranges for each cloud type. After that, we implemented the parameter ranges into the cloud-type classification algorithm. The whiskers inserted into Fig. 2 indicate the transmittance and patchiness ranges for different cloud-type classes. The CBHs and parameter ranges of radiation characteristics for all cloud types are listed in Table 1.

If the parameters did not fit to the parameter ranges of any of the listed cloud types (Table 1) or the data were missing, we classified the cases into separate classes based on whether the ceilometer did ("Base, no class") or did not ("No base, no class") capture a cloud base. As the ceilometer data were quality checked, the latter class basically contains data points when the sky was clear but the values of other parameters did not fit to the clear-sky parameter ranges, or the data were missing. Additionally, as the field of view of the ceilometer is narrow, the class contains data points when the cloud was not in the field of view of the ceilometer although there were clouds present.

We also examined the characteristics of the second and third cloud layers in cases of multilayered clouds as measured by the ceilometer. We classified these clouds based on the height of the second or third cloud base and characteristics defined by transmittance and patchiness. We used three height classes: "Low level" (LL), "Middle level" (ML) and "High level" (HL). If the second or third cloud base was below $2000 \mathrm{~m}$, the case was classified as low-level cloud; if between 2000 and $5000 \mathrm{~m}$, it was middle-level cloud; and if above $5000 \mathrm{~m}$, the class was high-level cloud (Houze, 2014). We classified the different cloud layers separately. Hence, even though, for example, the second cloud layer was middle level cloud, simultaneously there might also exist low- or 
Table 1. The cloud types and corresponding parameter ranges used in the algorithm to determine the different cloud types. No. of layers column refers to the number of the cloud layer that is used as a criterion. Notice that cumulus, cirrus + cirrocumulus + cirrostratus and low-level multilayered cloud classes have multiple criteria (see also Sect. 3.1). "n/a" represents not applicable.

\begin{tabular}{|c|c|c|c|c|}
\hline Cloud type & $\mathrm{CBH}(\mathrm{m})$ & Transmittance & $\begin{array}{l}\text { Patchiness } \\
\left(\mathrm{W} \mathrm{m}^{-2}\right)\end{array}$ & $\begin{array}{l}\text { No. of } \\
\text { layers }\end{array}$ \\
\hline \multirow[t]{2}{*}{ Cumulus $(\mathrm{Cu})$} & $<2000$ & $0.6-0.85$ & $\geq 200$ & 1 \\
\hline & $<2000$ & $>0.85$ & $>0$ & 1 \\
\hline Stratus (St) & $<2000$ & $<0.6$ & $<100$ & 1 \\
\hline Stratocumulus (Sc) & $<2000$ & $0.1-0.6$ & $\geq 100$ & 1 \\
\hline Nimbostratus (Ns) & $2000-3000$ & $<0.3$ & $<100$ & 1 \\
\hline Altocumulus + altostratus $(\mathrm{Ac}+\mathrm{As})$ & $2000-5000$ & $\geq 0.3$ & $<500$ & 1 \\
\hline Cirrus + cirrocumulus + cirrostratus & $\geq 4000$ & $0.85-1.1$ & $50-400$ & 1 \\
\hline$(\mathrm{Ci}+\mathrm{Cc}+\mathrm{Cs})$ & $\geq 4000$ & $0.5-0.85$ & $<400$ & 1 \\
\hline Clear + cirrus $($ clear $+\mathrm{Ci})$ & $\overline{\mathrm{n}} / \mathrm{a}$ & $0.85-1.05$ & $<50$ & 1 \\
\hline Cumulus + GRE $(\mathrm{Cu}+\mathrm{GRE})$ & $<2000$ & $>1$ & $\geq 200$ & 1 \\
\hline Cirrus + GRE $(\mathrm{Ci}+\mathrm{GRE})$ & $\geq 4000$ & $>1$ & $<400$ & 1 \\
\hline \multirow[t]{2}{*}{ Low level (LL) } & $<2000$ & & & 2 or 3 \\
\hline & $\begin{array}{l}\mathrm{CBH}_{\max }-\mathrm{CBH}_{\min }>1000 \mathrm{~m} \\
\text { and } \mathrm{CBH}_{\max }<2000 \mathrm{~m}\end{array}$ & & & 1 \\
\hline Middle level (ML) & $2000-5000$ & & & 2 or 3 \\
\hline High level (HL) & $\geq 5000$ & & & 2 or 3 \\
\hline Multilayer uniform (MuUni) & & $<0.5$ & $<120$ & 2 or 3 \\
\hline Multilayer transparent (MuTr) & & $>0.5$ & $<120$ & 2 or 3 \\
\hline Multilayer patchy (MuPa) & & $>0$ & $>120$ & 2 or 3 \\
\hline
\end{tabular}

high-level cloud layers. As other cloud layers could be difficult to detect above the first cloud layer with the ceilometer, an additional condition of low-level cloud layer was determined: if the difference between the 21 min moving maximum and minimum $\mathrm{CBH}\left(\mathrm{CBH}_{\max }-\mathrm{CBH}_{\min }\right)$ of the lowest cloud layer was more than $1000 \mathrm{~m}$ and $\mathrm{CBH}_{\max }$ was less than $2000 \mathrm{~m}$, the case was considered low-level multilayered cloud (Table 1).

We divided multilayered clouds into three characteristic classes: multilayer uniform (MuUni) for uniform and thick cloud layers such as stratus and nimbostratus, multilayer transparent $(\mathrm{MuTr})$ for uniform and transparent cloud layers like cirrostratus and multilayer patchy $(\mathrm{MuPa})$ for patchy clouds with varying transmittance such as altocumulus. However, the actual cloud types of the second and third cloud layers could not be determined with the current algorithm. Hence, multilayered classes rather inform of the presence of other cloud layers on top of the lowest, classified, cloud layer.

Before analyzing the cloud-type data produced by the algorithm, the performance of the algorithm was investigated. To test the performance, a third sample of 204 total-sky images was selected, and the cloud type determined through visual inspection. These cloud types were compared with the results of the algorithm in matrix form (Table 2). The results showed that the overall performance of the algorithm was $68.4 \%$. The performance depended on the cloud type. Some clouds, such as nimbostratus, cause very distinguish- able changes in solar radiation and hence were easily determined by the algorithm, while some other types, such as altocumulus and altostratus, cause similar changes as cirriform clouds and were more often mixed up by the algorithm. Indeed, most often the algorithm mixed up similar types of clouds, e.g., cumulus and stratus with stratocumulus. "Other types" include cases when the cloud type was changing, cases when two types of clouds were present in the same image, or cases when it was hard for the observer to distinguish between two similar cloud types (e.g., stratocumulus and stratus).

\subsection{Cloud properties}

We studied the seasonal variation of cloud occurrence measured with the ceilometer (Fig. 3a) and the pyranometer (Fig. 3b). We obtained the cloud occurrence by dividing the number of cloud observations in 1 month by the total number of data points in the month. Cloud occurrence calculated using ceilometer data (Fig. 3a) included all the data, whereas cloud occurrence calculated using the pyranometer data (Fig. 3b) included only times when SZA was less than $70^{\circ}$. The ceilometer measurements show a robust seasonal variation in cloud occurrence in Hyytiälä, with cloud occurrence being lower during summer months (56\%) and higher during winter months (79\%) (Fig. 3a). The overall cloud occurrence was about $66 \%$ and from March to September it was about $55 \%$ (Fig. 3a). Cloud occurrence calculated from 
Table 2. Contingency table presenting the performance of the cloud classification algorithm compared to the cloud types determined with visual inspection from total-sky images. The bolded values show the number of cases when the algorithm and visual inspection agreed.

\begin{tabular}{|c|c|c|c|c|c|c|c|c|c|c|}
\hline & & \multicolumn{8}{|c|}{ Algorithm } & \multirow[b]{2}{*}{$\begin{array}{r}\text { Agreement } \\
(\%)\end{array}$} \\
\hline & & Cumulus & Stratus & Stratocumulus & Nimbostratus & $\begin{array}{r}\text { Altocumulus + } \\
\text { altostratus }\end{array}$ & $\begin{array}{r}\text { Cirrus + } \\
\text { cirrocumulus }+ \\
\text { cirrostratus }\end{array}$ & $\begin{array}{r}\text { Clear }+ \\
\text { cirrus }\end{array}$ & $\begin{array}{l}\text { Other } \\
\text { types }\end{array}$ & \\
\hline \multirow{8}{*}{ 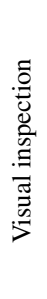 } & Cumulus & 19 & 0 & 3 & 0 & 0 & 0 & 1 & 3 & 73 \\
\hline & Stratus & 0 & 28 & 5 & 0 & 0 & 0 & 0 & 1 & 82 \\
\hline & Stratocumulus & 0 & 7 & 10 & 0 & 0 & 0 & 0 & 2 & 53 \\
\hline & Nimbostratus & 0 & 0 & 0 & 4 & 0 & 0 & 0 & 0 & 100 \\
\hline & Altocumulus + altostratus & 0 & 0 & 0 & 2 & 58 & 5 & 0 & 15 & 73 \\
\hline & $\begin{array}{l}\text { Cirrus + cirrocumulus + } \\
\text { cirrostratus }\end{array}$ & 0 & 0 & 0 & 0 & 5 & 11 & 0 & 6 & 50 \\
\hline & Clear + cirrus & 0 & 0 & 0 & 0 & 0 & 0 & 15 & 6 & 71 \\
\hline & Other types & 1 & 0 & 1 & 0 & 4 & 0 & 0 & 2 & 25 \\
\hline
\end{tabular}

the pyranometer was higher ( $73 \%$ ) compared to the ceilometer measurements (Fig. 3b).

Diurnal variation of cloud observations by the ceilometer in different seasons is shown in Fig. B1. A diurnal cycle in cloud occurrence was observed in summertime (Fig. B1b). The cloud occurrence had a maximum around 14:00 LT (UTC+2), likely being associated with the development of convective clouds. In May and September, a robust diurnal cycle was also observed, whereas in other months the variation was absent (Fig. B1a and c). We did not investigate the diurnal variation from the pyranometer measurements as the method is limited by SZA and hence the observations were not distributed evenly throughout the day.

From the ceilometer data, we could retrieve the occurrence of the two-layered and three-layered clouds. The second and the third cloud bases were observed about $2 \%-10 \%$ and less than $1 \%$ of the time, respectively, depending on the month (Fig. B2). Hence, the frequency of the times when singlelayered clouds were detected by the ceilometer was approximately the same as the observed cloudiness in total. Both the second and third cloud layers seemed to have higher frequencies of occurrence during summertime compared to winter, even though there were substantial differences between the years (Fig. B2). When a multilayered cloud was observed, it was a two-layered cloud in $92 \%$ of the cases.

To identify the most common $\mathrm{CBHs}$ observed over Hyytiälä, we investigated the seasonal (Fig. 4) and diurnal (Fig. B3) variation of CBHs measured with the ceilometer. In each month, we divided every $\mathrm{CBH}$ record from the lowest cloud layer into $400 \mathrm{~m}$ bins. We calculated the frequency of $\mathrm{CBH}$ records in each bin as a ratio between the number of $\mathrm{CBH}$ records in the bin and the total number of $\mathrm{CBH}$ records in that month. Figure 4 shows that when a cloud base was observed, the most frequently observed CBH was below $800 \mathrm{~m}$ for all months, although the relative amount of CBH records below $800 \mathrm{~m}$ was higher in winter than in summer. Figure 4 also shows that in spring and summer the $\mathrm{CBH}$ distribution was more dispersed, and a second maximum at about $1600 \mathrm{~m}$ was detected. The measured CBHs were most likely associated with cumulus clouds as they were more often observed in summer (see Fig. 5 in Sect. 3.3). This is also supported by the fact that a pronounced diurnal cycle in $\mathrm{CBH}$, with higher values in afternoon compared to morning, was measured in summer, whereas in winter no diurnal cycle was observed (Fig. B3). In summertime, the frequently detected CBHs around 3000$4000 \mathrm{~m}$ are probably middle-level altocumulus and altostratus clouds. Overall, low clouds $(\mathrm{CBH}<2000 \mathrm{~m})$ were observed $87 \%$ of the time when clouds were detected, middle clouds $(2000 \mathrm{~m}<\mathrm{CBH}<5000 \mathrm{~m})$ were detected $13 \%$, and high clouds $(\mathrm{CBH}>5000 \mathrm{~m})$ were detected $1 \%$ of the time.

The seasonal variation of $\mathrm{CBH}$ distribution of all clouds, as well as single-, two- and three-layered clouds, are presented in Fig. B4. It confirms the observation of singlelayered clouds dominating the $\mathrm{CBH}$ distribution based on ceilometer data that we found also in Figs. 3 and B2, as the distribution of single-layered clouds resembles the distribution of total observed cloudiness. The seasonal variation of the CBHs of multilayered clouds reflects the seasonal variation of the lowest cloud layer (Fig. 4).

Figure B5 displays the height differences between cloud layers in different seasons. In all the seasons, the most common height difference between all the layers (first and second in two-layered clouds, first and second in three-layered clouds, and second and third in three-layered clouds) was less than $400 \mathrm{~m}(50 \%-70 \%)$. Towards the higher end, the distribution decreased gradually. The large distances between cloud layers were slightly more common in autumn and winter than in spring and summer (Fig. B5). In cases when three cloud layers were detected, the distance between the first and the second cloud layer was usually smaller than the distance between the second and the third cloud layer. Also, the first and the second cloud layer, in cases with three-layered clouds, were found more often close to each other (distance less than $400 \mathrm{~m}$ ) than the first and the second cloud layer in two-layered cloud cases (Fig. B5). 

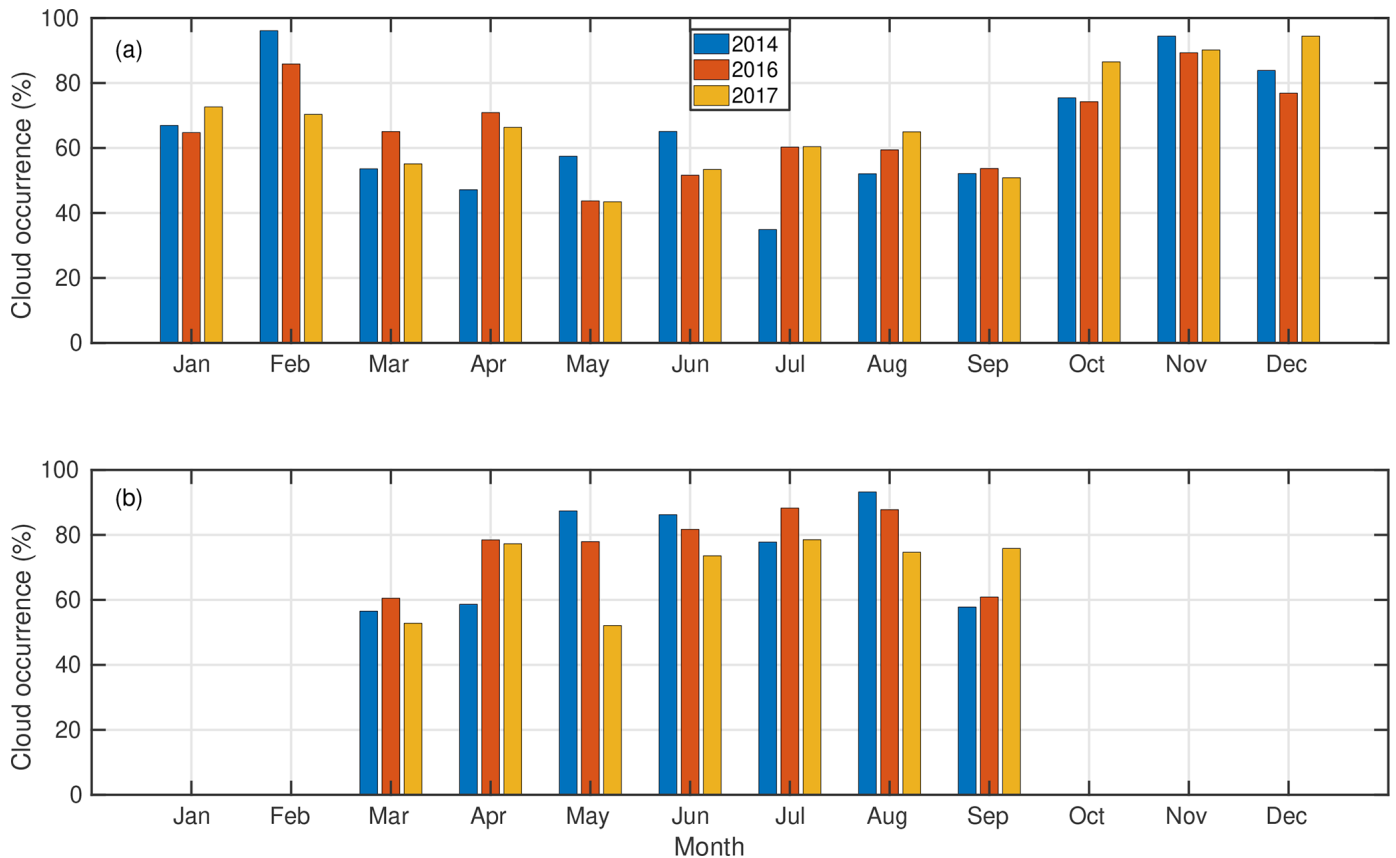

Figure 3. The monthly-average cloud occurrence observed over Hyytiälä based on (a) the ceilometer data and (b) the pyranometer data. The pyranometer data were limited to values when SZA was less than $70^{\circ}$.
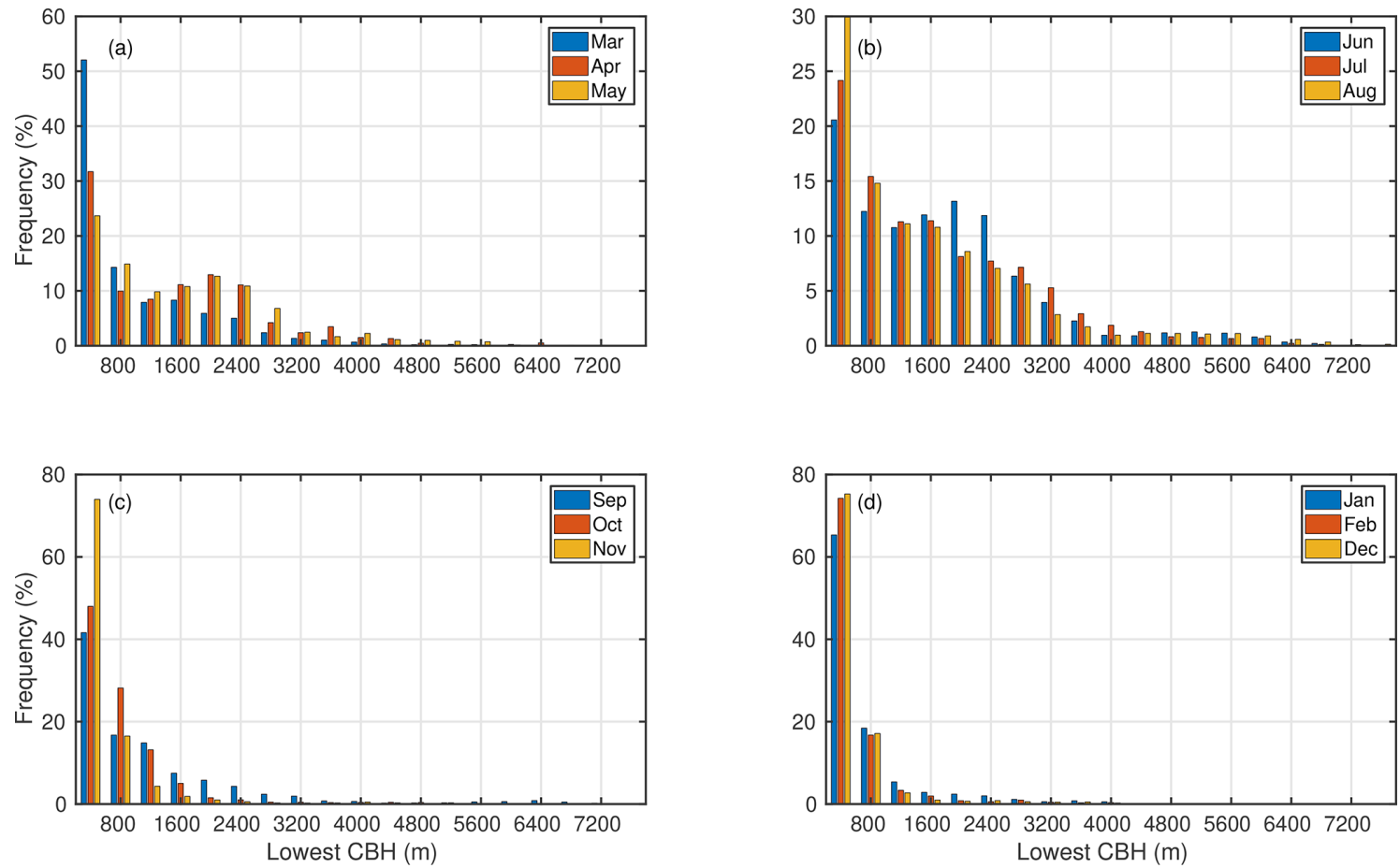

Figure 4. The number of $\mathrm{CBH}$ observations, from the lowest level of the ceilometer, in each $400 \mathrm{~m}$ height bin in 1 month with respect to the total number of observed cloud bases in that month in (a) spring, (b) summer, (c) autumn and (d) winter months. Notice the differences in $y$-axis scaling. 

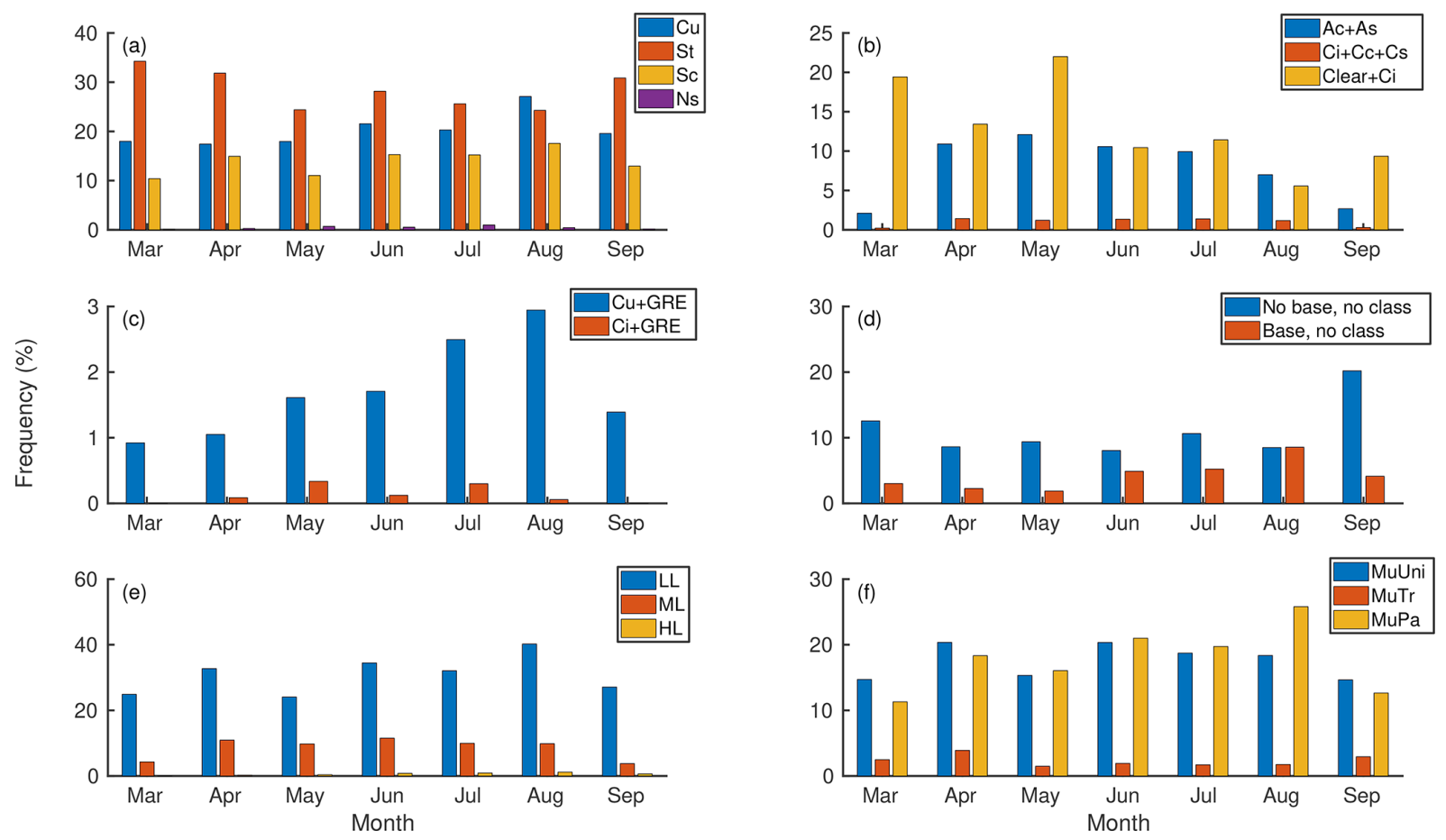

Figure 5. Occurrence of cloud types with respect to total number of data points monthly. (a) Low clouds, (b) middle- and high-level clouds, (c) cumulus and cirrus clouds causing GRE, (d) cases when the cloud class could not be determined in situations when the ceilometer did or did not detect a cloud base, (e) height classes of multilayered clouds, and (f) characteristic classes of multilayered clouds. Notice the differences in $y$-axis scaling.

\subsection{Cloud statistics using the new cloud algorithm}

The algorithm was applied to the data from 2014 and 20162017 from SMEAR II. Only cases when SZA was less than $70^{\circ}$ were included. Figure 5 displays the monthly occurrence of each cloud type with respect to the total number of data points in that month. Figure 5a-d represent the classified cloud types of the lowest cloud layer detected by the ceilometer. As clear-sky cases and cases when the cloud class could not be determined are included (Fig. 5c and d), Fig. 5a$\mathrm{d}$ will give the frequency of occurrence of each cloud type by month. Thereby, summing the percentages corresponding to these classes (Fig. 5a-d) monthly will give $100 \%$. Figure $5 \mathrm{e}$ and $\mathrm{f}$ represent the second and the third cloud layer in multilayered cloud cases. Overall, the most commonly observed cloud types were stratus (33\%), cumulus (24\%) and stratocumulus (17\%), which altogether comprised approximately $75 \%$ of clouds. Cirriform clouds were rarely observed, accounting only for about $1 \%$ of the classified clouds. Clear sky and cirrus cases contributed $15 \%$ to the classified cases.

The seasonal variation of each cloud type was studied (Fig. 5). Many cloud types showed a robust seasonal variation. Stratus clouds were slightly less frequent during summertime, whereas others had a maximum in occurrence during spring or summer. Altocumulus plus altostratus and clear plus cirrus classes had maxima in occurrence already in spring, while cumulus had a maximum in August. Variation in the frequency of occurrence of stratocumulus, nimbostratus and cirriform clouds was less clear. The lack of variation of cirriform clouds may partially be related to the relatively high occurrence of clear-sky and cirrus cases in summertime, because this class also contains cirriform clouds as they cannot be distinguished from the clear sky (Fig. 5b). The seasonal variation of cumulus clouds causing global radiation enhancement followed the variation of cumulus cloud occurrence. Also, cirrus clouds causing global radiation enhancement were more frequent during summertime. It should, however, be noted that wintertime was not included.

The relative share of "No base, no class" cases peaked in the beginning and end of the period of investigation (Fig. 5d). This is generally related to discrepancies between the field of view of the instruments when SZA is high: the ceilometer is always pointing upwards, detecting only clouds that are directly above it, whereas the pyranometer can detect the decrease in solar radiation caused by clouds whenever there is a cloud between the instrument and the Sun. This also illustrates why we chose to use the threshold of $70^{\circ}$ for SZA.

Figure 5e shows that the most commonly observed multilayered cloud type was the low-level class $(79 \%)$. This is in line with the CBH observations (Fig. B4). Multilayered clouds with a middle-level cloud layer were also ob- 
served often (23\%), whereas high-level multilayered clouds were seldom observed $(2 \%)$. Overall, the relative fraction of high clouds was smaller compared to the other cloud types (Figs. 5a, b, 3 and B2).

Multilayered clouds were characterized by low transparency: $47 \%$ of the clouds were patchy and $45 \%$ uniform (Fig. 5f). Multilayered clouds were transparent in $6 \%$ of the cases. The reason why the numbers do not sum up to $100 \%$ is the missing radiation data needed for the calculation of transmittance and patchiness.

When multilayered clouds were present, the lowest cloud layer was most often stratus (41\%), stratocumulus (27\%) or cumulus $(21 \%)$. The first cloud layer was determined as low cloud in $90 \%$ of the multilayered cloud cases. Hence, there was typically a low-cloud layer above another lowcloud layer. This can also be seen in Figs. B4 and B5 as the distance between the cloud layers was usually less than $400 \mathrm{~m}$.

The diurnal variation of cloud types shows that low cumulus clouds peak in the afternoon (Fig. B6a). Similar diurnal variation can also be seen in the frequency of low and patchy multilayered clouds (Fig. B6e and f). Nimbostratus, altocumulus plus altostratus and cirriform clouds were more common in the morning and evening compared to noon (Fig. B6a and b). Clear sky plus cirrus clouds were most often observed in the morning (Fig. B6b). Global radiation enhancement during the presence of cumulus clouds was more common in late afternoon and evenings compared to mornings, while during the presence of cirrus clouds, it took place both in the mornings and evenings (Fig. B6c).

\subsection{Applications of the algorithm}

In this section, we briefly introduce some applications of the new algorithm, which could be analyzed further in the future.

\subsubsection{Clearness index}

The clearness index, also known as brightness parameter (Kulmala et al., 2010, 2014a) or cloudiness parameter (Dada et al., 2017), has been used as a simplified measure of the prevailing cloudiness in terms of "cloudy" or "clear sky" when studying aerosol-cloud interactions. In Kulmala et al. (2010), the limit of clear-sky conditions was set to $C>0.50$, in Kulmala et al. (2014a) it was $C>0.60$ and in Dada et al. (2017) it was $C>0.70$. The limit of cloudy sky in all three articles was $C<0.30$.

Figure 6 demonstrates the clearness index values obtained when different cloud types were present. We can see that even when the clearness index was above 0.7 (black line in Fig. 6), different types of clouds were present. According to our results, cumulus, altocumulus, altostratus and cirriform clouds occurred when the clearness index was above the 0.6 or 0.7 limit. Only stratus and nimbostratus were not observed with the lowest clearness index limit $(C>0.5)$.

\subsubsection{Estimation of cloud optical depth using transmittance}

Figure 7 shows daytime (09:00-15:00 LT) transmittance (calculated using Eq. 1), as a function of measured COD between 17 July and 31 August 2014 in Hyytiälä. The data have been divided into three different SZA ranges $\left(40^{\circ} \leq\right.$ $\mathrm{SZA}<50^{\circ}, 50^{\circ} \leq \mathrm{SZA}<60^{\circ}$ and $60^{\circ} \leq \mathrm{SZA}<70^{\circ}$ ). The data points corresponding to situations of low patchiness $\left(\mathrm{PA}<100 \mathrm{~W} \mathrm{~m}^{-2}\right)$ are shown by red markers. The black curves in Fig. 7 represent the theoretical relation between transmittance and COD, calculated using Eq. (8). For each SZA range, the theoretical curve was calculated using SZA in the middle of the range, i.e., 45,55 and $65^{\circ}$, respectively. The markers follow the theoretical curve well, especially those that are related to clouds with low patchiness. The exception in Fig. 7a corresponds to $2 \mathrm{~d}$ when thick, 3D clouds developed. Hence, transmittance can be used for estimating COD for nonpatchy clouds during daytime when measured COD is not available.

\subsection{Discussion}

Karlsson (2003), Pipatti et al. (2009) and Joro et al. (2010) reported similar frequencies of cloud occurrence and yearly variations in Finland, based on satellite and surface observations, as we found in Hyytiälä from the ceilometer measurements (Fig. 3a). The cloud occurrence values retrieved with the pyranometer method were found to be higher than those measured with the ceilometer, and the seasonal variation was absent (Fig. 3b). One reason for the difference between ceilometer and pyranometer results might be the limited vertical resolution of the ceilometer, in which case some of the highest clouds would not be detected, lowering the observed cloud occurrence. As the pyranometer only measures the attenuation of solar radiation, the altitude of the cloud does not affect its performance. However, this explanation is improbable, because the cloud occurrence estimated using the pyranometer method gave higher values than those found in the literature. Furthermore, several studies mention the capability of ceilometers to detect clouds reliably, though their field of view is narrow and performance is better with low clouds (Rodriguez, 1998; Kalb et al., 2004).

In Fig. 3, the cloud occurrence from the ceilometer observations also contained nighttime data points contrarily to the pyranometer data which were filtered by SZA. When only daytime (09:00-15:00 LT) data from the time when SZA was less than $70^{\circ}$ were used in both methods, the difference between the calculated cloud occurrences was reduced slightly (Fig. B7). The cloud occurrence estimated from the ceilometer measurements increased, presumably because the cloud occurrence had a maximum during daytime (Fig. B1). Additionally, the cloud occurrence from the pyranometer method decreased, implicating that the pyranometer method overestimated the cloudiness when data from early mornings and 


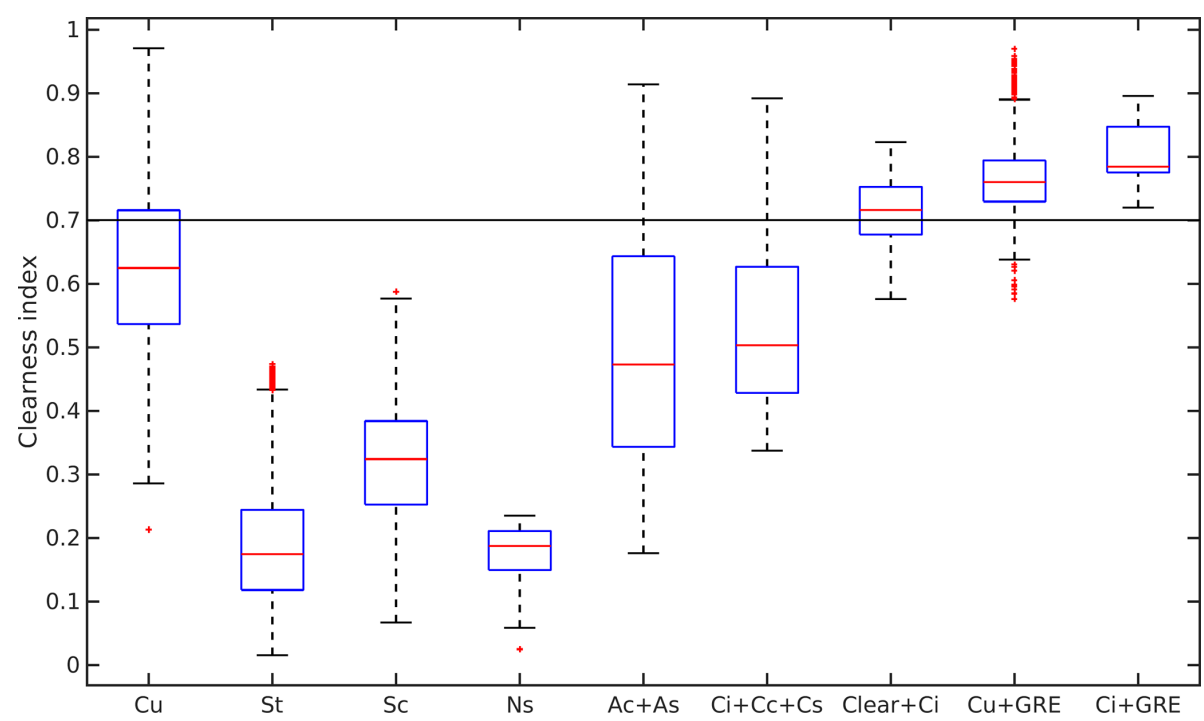

Figure 6. Obtained clearness index values when different types of clouds were present. The clearness index was calculated as 21 min running average. The values are from daytime (09:00-15:00 LT) during the maximum growing season (from June to August). Red lines show the median values; lower and upper edges of the boxes are 25 th and 75 th percentiles, respectively; and whiskers correspond to $99.3 \%$ coverage of the data. More extreme values are represented separately with red "+" symbols. The black line represents the limit for clear sky used, for example, in Dada et al. (2017).
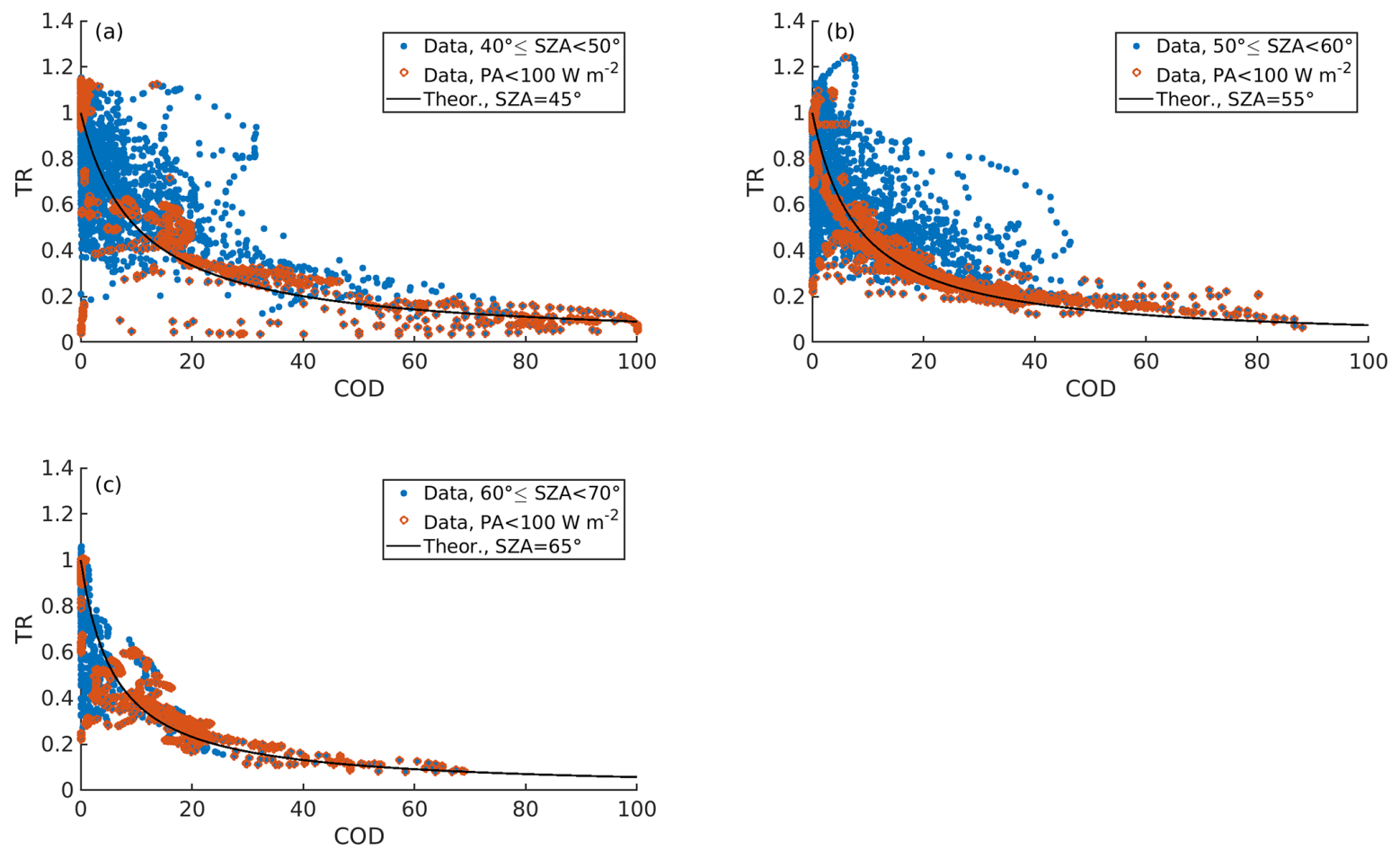

Figure 7. Transmittance as a function of measured COD during daytime (09:00-15:00 LT). Blue markers represent all data points and red markers represent data points during which the patchiness was below $100 \mathrm{~W} \mathrm{~m}^{-2}$. The data have been divided based on SZA: (a) represents cases when $40^{\circ} \leq \mathrm{SZA}<50^{\circ}$, (b) $50^{\circ} \leq \mathrm{SZA}<60^{\circ}$, and (c) the cases when $60^{\circ} \leq \mathrm{SZA}<70^{\circ}$. The black curve follows the theoretical relation between transmittance and COD (calculated using Eq. 8). It has been calculated using the SZA in the middle of the range: (a) $45^{\circ}$, (b) $55^{\circ}$ and (c) $65^{\circ}$. 
evenings were included, despite the filtering with SZA. Due to Finland's northern location, SZA is high throughout the year compared to locations closer to the Equator. Hence, as the pyranometer method is sensitive to SZA, the most reliable results are obtained during the hours when the Sun is at the highest position, especially in summertime when cloud occurrence had a diurnal cycle (Fig. B1). Moreover, as shown also in Fig. 6, the simple limits set for determining cloudiness may not be efficient in all cases.

The cloud occurrence by the pyranometer was also modulated by the averaging over a $21 \mathrm{~min}$ time window. Thereby, cloudless data points might also have been considered cloudy, whereas the ceilometer separated clear and cloudy periods. However, the best practice to separate between clear and cloudy cases depends on the application. For example, if the objective is to quantify albedo, it is reasonable to rely on ceilometer data. Yet, if the objective is to study the effect of clouds generally on the ecosystem, pyranometer data averaged over $21 \mathrm{~min}$ are more appropriate in describing the integrated effect of changing light conditions on plants.

Despite the good agreement with the frequency of the cloud occurrence with values found in other studies, we are likely to miss the occurrence of the second and third cloud layers (Fig. B2). Costa-Surós et al. (2013) found a similar occurrence of multilayered clouds in Girona, Spain, using an identical ceilometer. They compared their results with observations from the nearby airport and noticed that the ceilometer overestimated the occurrence of single-layered clouds. They hypothesized that it might be due to the occultation of the laser pulse by the first cloud layer, and the fact that the vertical resolution of the ceilometer was too low to detect all high clouds. The occultation by the first cloud layer might be an important phenomenon in Hyytiälä, where low and stratiform clouds were frequently observed (Fig. 5). Other studies have also shown higher frequencies of multilayered clouds (Wang and Rossow, 1995; Wang et al., 2000; Li et al., 2015) and differences in detection of cloud layers depending on the method (Wang et al., 1999, 2000; Rossow et al., 2005; Rossow and Zhang, 2010). Additionally, when multilayered clouds were observed, they were predominately twolayered clouds, having two low-cloud layers on top of each other (Fig. B4). Comparing the results with previous publications, this indicates that we miss middle- and high-level clouds (Rossow et al., 2005; IPCC, 2013; Li et al., 2015).

The high contribution of low single-layered clouds also modulates the observed CBHs. Joro et al. (2010) investigated cloudiness in Finland by combining satellite and ceilometer data. They found that in February low clouds dominated the CBH distribution, while in August there was a second maximum around $2500 \mathrm{~m}$. We found a similar second maximum in April, May and June, but in August the distribution decreased towards the end of higher CBHs (Figs. 4 and B4). The second maximum that we found was around $1600 \mathrm{~m}$, i.e., at lower altitude compared to results by Joro et al. (2010). However, Joro et al. (2010) reported results from only 2 months, whereas we had data from 3 years. Despite the high frequency of low clouds, our findings produce a distribution of CBHs similar to Wang and Rossow (1995) and Wang et al. (2000), who reported an averaged CBH distribution of satellite and rawinsonde data, respectively, from many stations.

Our observation that there is often a low-level cloud layer on top of low clouds explains the small difference between cloud layers (Fig. B5). Wang and Rossow (1995) reported separation distances between cloud layers. They found that most often the separation distance was about $1 \mathrm{~km}$, whereas we found that the distance between two consecutive cloud layers was about $400 \mathrm{~m}$. However, the results are not completely comparable due to different data analyzing procedures.

The cloud classification algorithm was able to produce the correct cloud type in about $70 \%$ of the cases (Table 2). When other types of clouds than those that are classified by the algorithm were excluded, the performance was up to $84 \%$. The performance was better with clouds having distinguishable effects on radiative conditions. For example, for very opaque nimbostratus clouds, the algorithm identified correctly in $100 \%$ of the cases. The least accuracy was obtained with cirriform clouds (50\%). This may be caused by the weaker detection of the high clouds by the ceilometer.

The performance of our algorithm was significantly better compared to the $45 \%$ agreement of the original algorithm by Duchon and O'Malley (1999) and $45 \%$ agreement of another algorithm also employing solar radiation measurements (Calbó et al., 2001). Moreover, when Calbó et al. (2001) reduced the number of cloud classes from nine to five, the classifier reached $58 \%$ agreement with human-observed cloud classes. The performance of the new algorithm was approximately similar to the average performance of the reviewed cloud classification algorithms in Tapakis and Charalambides (2013). Our simple algorithm is based on measurements by two common instruments: pyranometer and ceilometer; hence, the good performance compared to other, more sophisticated or expensive, methods is remarkable.

We found that low clouds were frequently observed (Fig. 5). When comparing the results with surface observations from Finland, we found that the algorithm produced approximately a similar frequency of occurrence and diurnal variation (Figs. 5 and B6) as the observations in Eastman and Warren (2014) and Climatic Atlas of Clouds Over Land and Ocean (available online at https://atmos.uw.edu/CloudMap/, last access: 10 January 2020; method explained in Hahn and Warren, 2007). However, the frequency of middle (and especially high cirriform clouds) was up to 10 -fold lower compared to the values in Climatic Atlas of Clouds Over Land and Ocean (Fig. 5b). This can partly be explained by the fact that our clear-sky class also contained cirrus cloud cases. The better accuracy for low clouds was, however, likely caused by the limitations of the ceilometer to observe high clouds as discussed above. Moreover, Li et al. (2015) reported that 
middle- and high-level clouds often coexist with other types of clouds. According to their results, at $60^{\circ} \mathrm{N}$ high clouds are often observed together with low- or middle-level clouds. We could not capture cases with many cloud layers because of the occultation of the laser pulse. When studying our results, high-level multilayered clouds were seldom observed but rather two low-cloud layers coexisted (Fig. 5).

Many cloud types showed variation during the measurement period, having a maximum in summertime, e.g., cumulus clouds peaking in late summer (Fig. 5), except for stratus that was more frequent during spring and autumn. The algorithm reproduced the seasonal variation of clouds reported in Climatic Atlas of Clouds Over Land and Ocean. However, as our analysis does not cover winter months, some possible discrepancies were observed: according to Climatic Atlas of Clouds Over Land and Ocean, the occurrence of nimbostratus has a minimum in summertime. In our study, nimbostratus showed a relatively constant frequency of occurrence from April to August but was almost absent in March and September. The overall performance of the simple algorithm was very good, but we cannot conclude the deviation from the cloud observations reported in Climatic Atlas of Clouds Over Land and Ocean.

The clearness index is defined as the ratio between the measured global radiation and calculated radiation at the top of the atmosphere and has been used as an indicator of clear sky or the presence of clouds. We found that cumulus, altocumulus, altostratus and cirriform clouds were present when clearness index was above 0.7, which has been used as a threshold for clear-sky conditions when studying aerosolcloud interactions. Thus, the studies defining clear-sky cases based on clearness index may be biased if a threshold value that is not high enough is used. For example, Dada et al. (2017) concluded that aerosol formation was enhanced under clear-sky conditions. Yet, it is possible that there could be a mechanism similar to that in the tropics where aerosol particles formed in the upper layers of the atmosphere are delivered to the surface by convective plumes that are often enhanced in the presence of boundary layer clouds (Perry and Hobbs, 1994; Twohy et al., 2002; Waddicor et al., 2012; Leino et al., 2019; Lampilahti et al., 2020). Hence, cloudy cases falsely classified as clear sky might have complicated the analyses related to ecosystem-atmosphere interactions and new particle formation, hindering the understanding of the processes occurring in the boundary layer (Kulmala et al., 2010, 2014a; Dada et al., 2017). Our results show that a single parameter may not indicate clear-sky conditions reliably; thus, when using clearness index in analysis, extra care should be taken when drawing the conclusions. Our algorithm is a new tool for future research regarding the radiation partitioning and modified processes.

\section{Conclusions}

The present study included a formulation of a cloud-type classification algorithm and investigation of cloud properties at the SMEAR II measurement site in Hyytiälä, Finland. The overall cloud occurrence measured by the ceilometer was in agreement with the reported values in literature, though the frequencies of single-layered clouds were likely overestimated and the occurrence of middle- and high-level clouds underestimated. We hypothesize that this is caused by the facts that the vertical maximum measurement height of the ceilometer did not allow it to detect all the high clouds and that the occultation of the laser pulse by the lowest cloud layer prevented the observation of other cloud layers.

The developed cloud classification algorithm is based on two variables measured continuously at the station: global radiation and $\mathrm{CBH}$. Despite the simplicity of the algorithm, it can identify seven different cloud types along with classification of multilayered clouds based on their base height and characteristics (uniform, transparent or patchy). The overall performance of the algorithm was almost $70 \%$, indicating a good ability to distinguish cloud types observed over a boreal forest. The algorithm may, however, be utilized also in other environments. Because the algorithm is based on attenuation of solar radiation, the performance is better with cloud types that have a distinguishable impact on radiative conditions on the Earth, such as nimbostratus. We are confident that the algorithm is able to reproduce the cloud types rather reliably in common situations, though it is probable that it does not reproduce all the high multilayered clouds due to the limitations of the performance of the ceilometer, as discussed above. Indeed, we showed that low and optically thick stratiform and cumulus clouds occurred frequently, indicating the high probability for occultation of the laser pulse.

The clearness index is defined as the ratio between the measured global radiation and calculated radiation at the top of the atmosphere and has been used as an indicator of a clear sky or the presence of clouds. We found that cumulus, altocumulus, altostratus and cirriform clouds were present when clearness index was above the 0.7 threshold, which has been used as a limit for clear sky when studying aerosolcloud interactions. Thus, the studies defining clear-sky cases based on clearness index may be biased. A high clearness index threshold is a deficient criterion as in the presence of patchy clouds the clearness index may still be periodically high. Hence, the criterion should concern conditions with high transmittance and low patchiness. The new algorithm may be utilized in the future to distinguish clear-sky conditions in a more reliable way when studying ecosystematmosphere interactions.

As the focus of this study was in the development of the algorithm, we only used data from 3 years. The measurements of the $\mathrm{CBH}$ and the global radiation at SMEAR II have been ongoing since 2008; therefore, the analysis can easily be extended in the future for longer time periods and different data 
sets. The current algorithm is the first one indicating the prevailing cloud types at SMEAR II, and we encourage readers to use it in studies related to boundary layer interactions involving radiation processes and clouds. 


\section{Appendix A: Materials and methods}

\section{A1 Site and data set}

When comparing the performance of the cloud algorithm using SMEAR II and ARM ceilometers, the results are similar on a daily scale (Fig. A1). However, the distance between the ceilometers led to different results if data from certain moments of time were examined. Thus, the classification algorithm developed with one instrument is also applicable with another instrument.
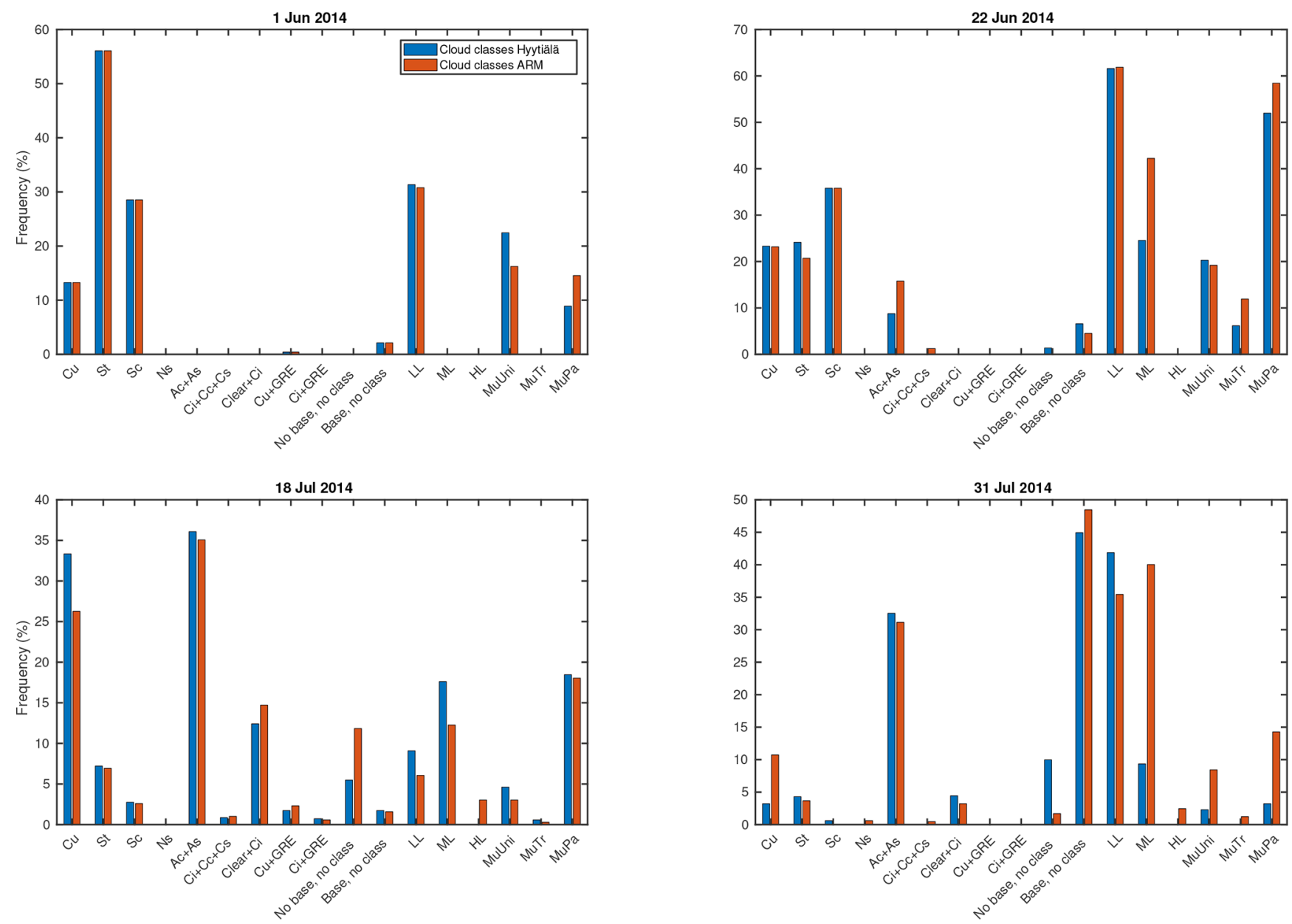

Figure A1. Comparison of the frequencies of the produced cloud types with the ceilometer of SMEAR II (blue) and ARM campaign (red) during four random days. The frequencies were obtained by dividing the number of cloud-type records by the total number of data points in the day. The abbreviations of the cloud types are found in Table 1. Note the different limits of the $y$ axes. 


\section{Appendix B: Results and discussion}

\section{B1 Cloud properties}
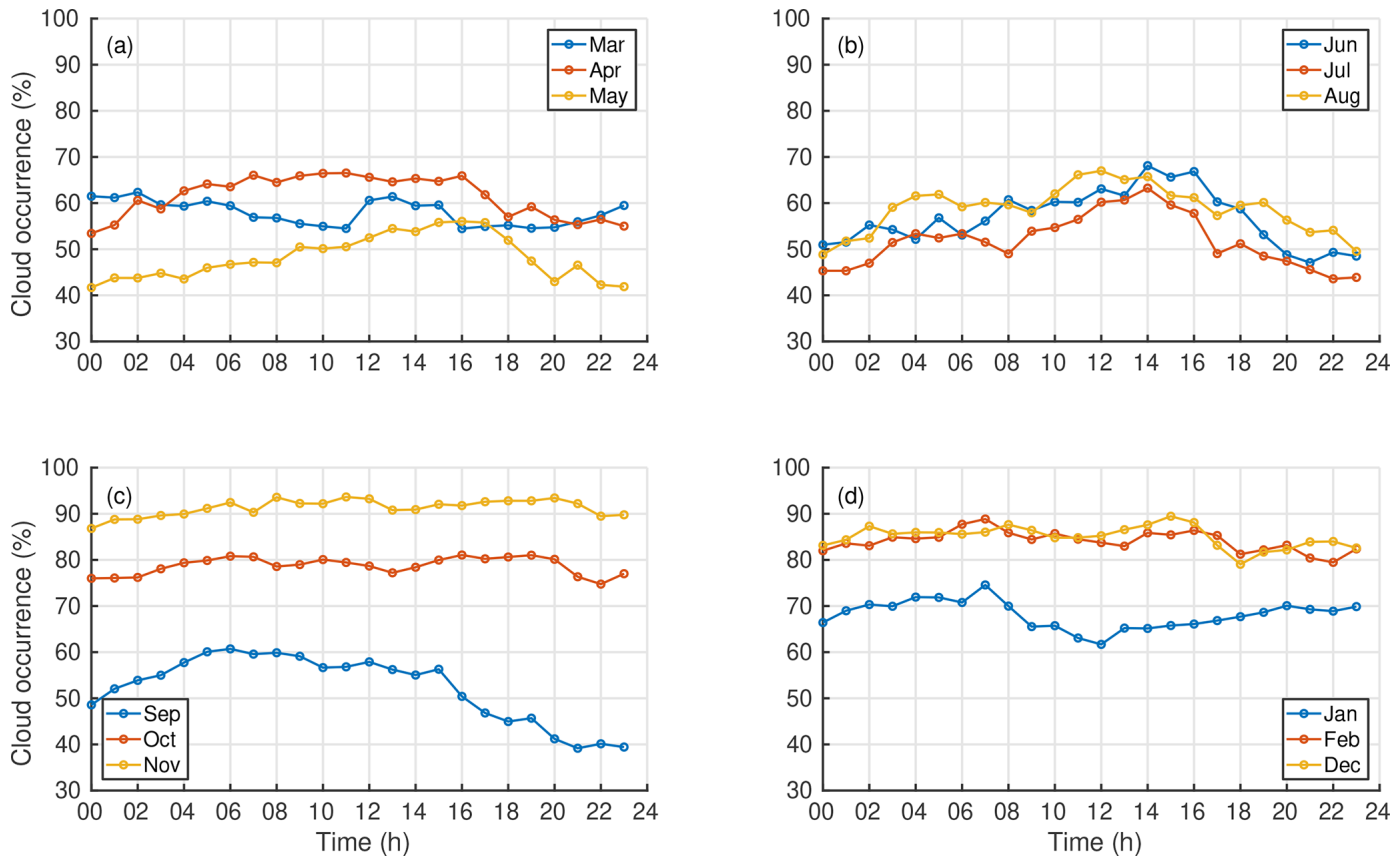

Figure B1. Diurnal variation of the cloud occurrence in (a) spring, (b) summer, (c) autumn and (d) winter months. The figure contains data from the lowest cloud layer measured with the ceilometer. The number of cloud observations was divided by the total number of data points in the certain hour to obtain the relative cloud occurrence.

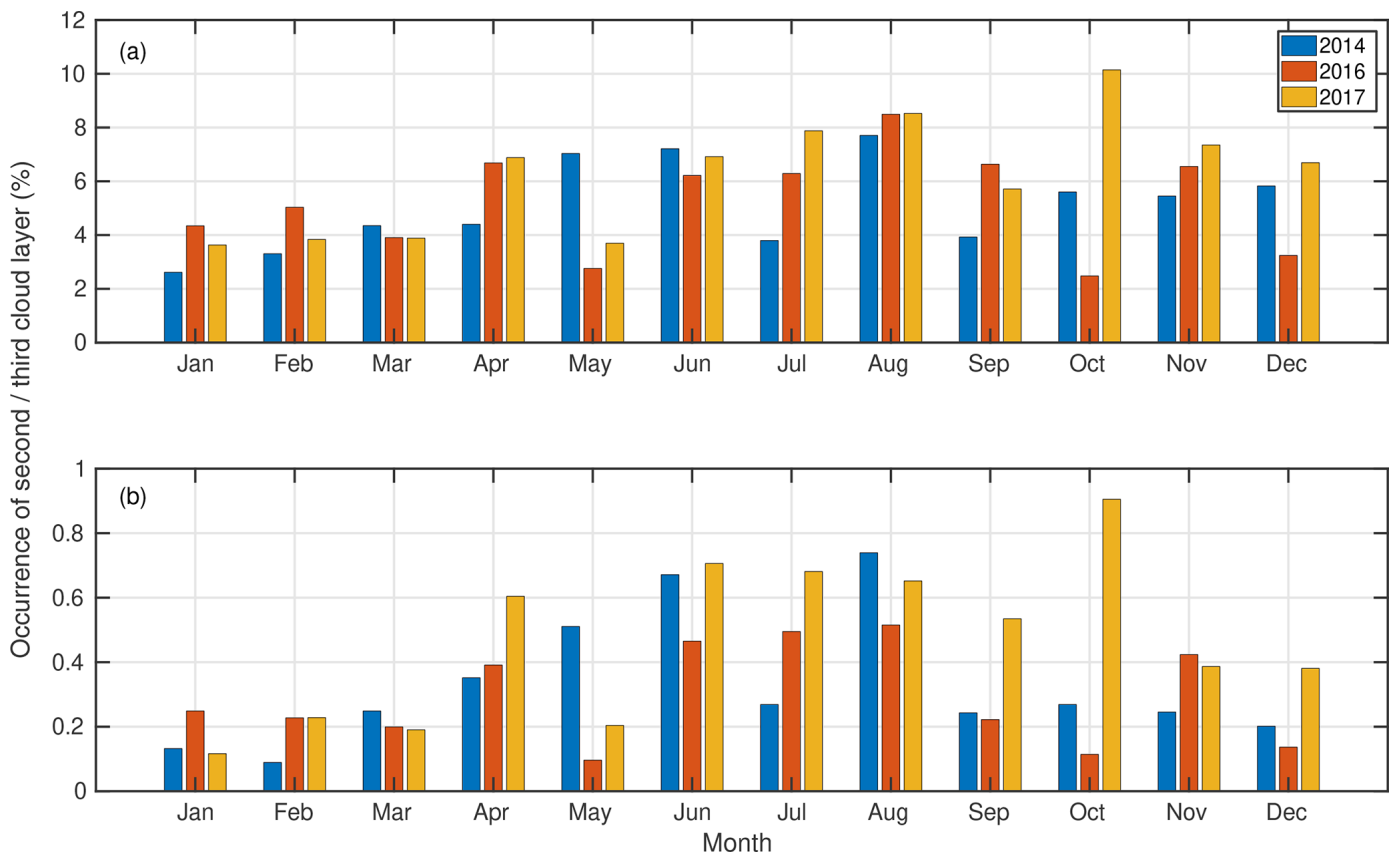

Figure B2. Monthly-average occurrence of (a) the second and (b) the third cloud layers over Hyytiälä. Note the different limits of the $y$ axes. 

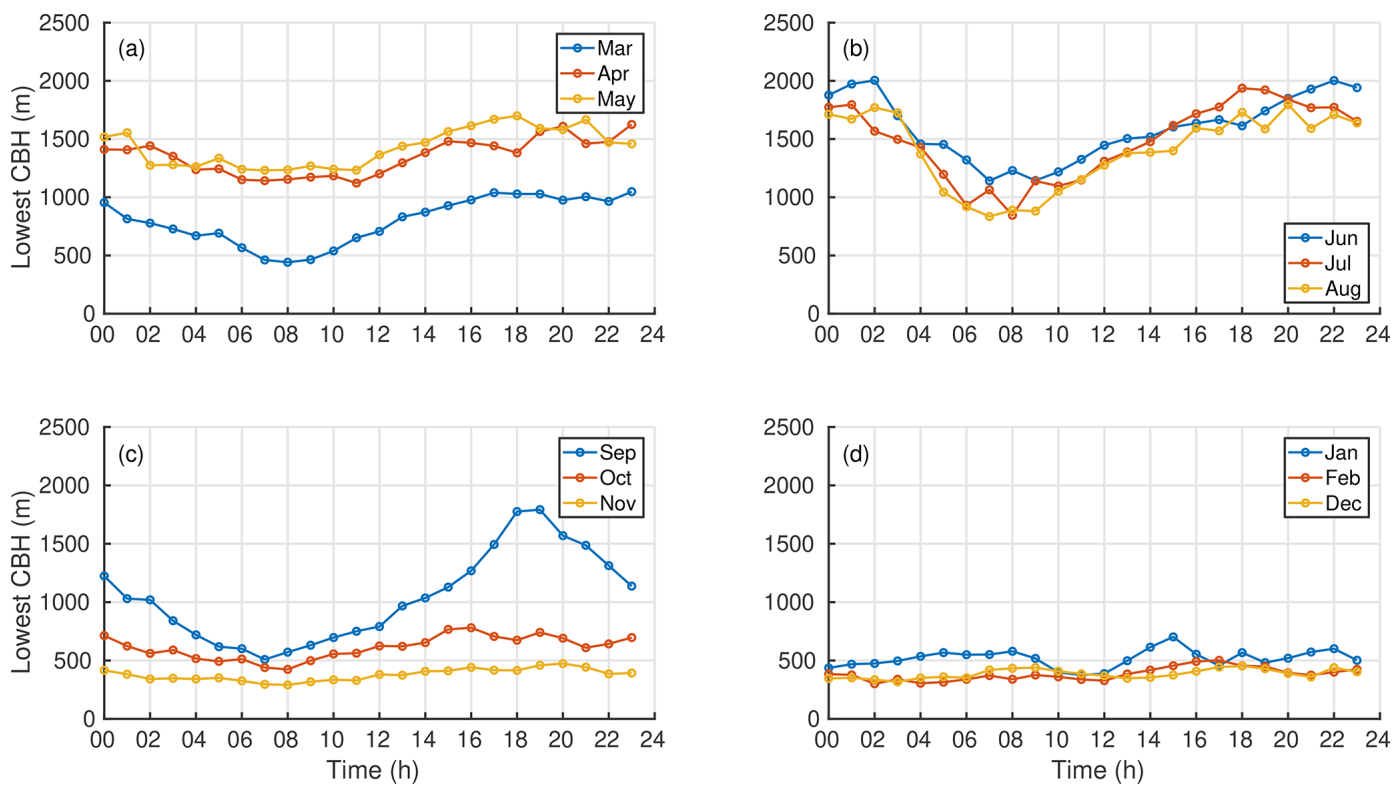

Figure B3. Hourly averaged CBH of the lowest cloud layer from (a) spring, (b) summer, (c) autumn and (d) winter months. Before calculating the hourly averages, the data from all 3 years were first separated by month.
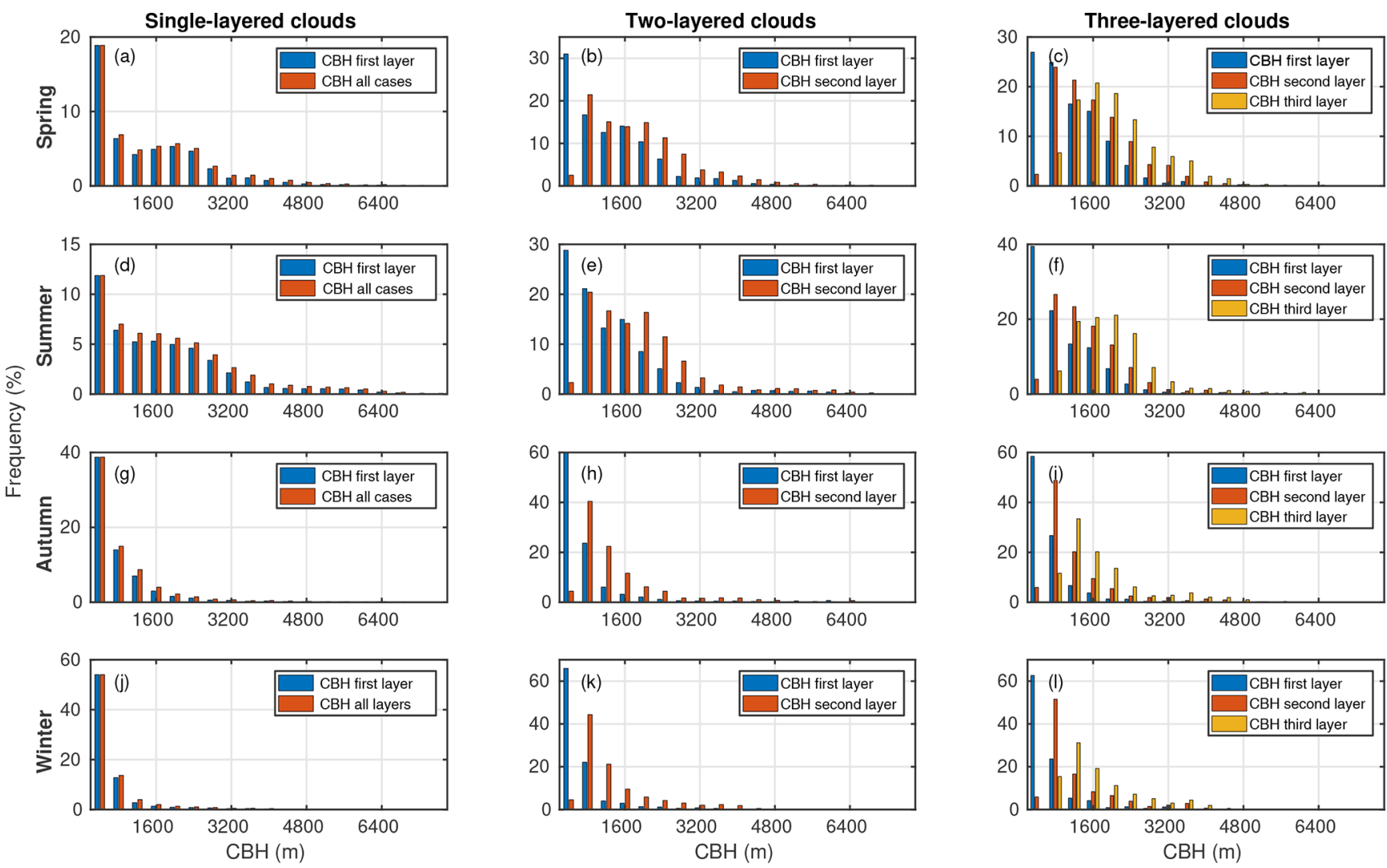

Figure B4. The frequency of single-layered clouds (a, d, $\mathbf{g}, \mathbf{j})$, two-layered clouds $(\mathbf{b}, \mathbf{e}, \mathbf{h}, \mathbf{k})$ and three-layered clouds (c, $\mathbf{f}, \mathbf{i}, \mathbf{l})$. The CBH records of one season were divided into $400 \mathrm{~m}$ bins, and the frequencies were obtained by dividing the number of $\mathrm{CBH}$ records in each bin by the total number of CBH records in the season. Panels (a)-(c) represent spring, (d)-(f) summer, (g)-(i) autumn and (j)-(l) winter. Note the different limits of the $y$ axes. 

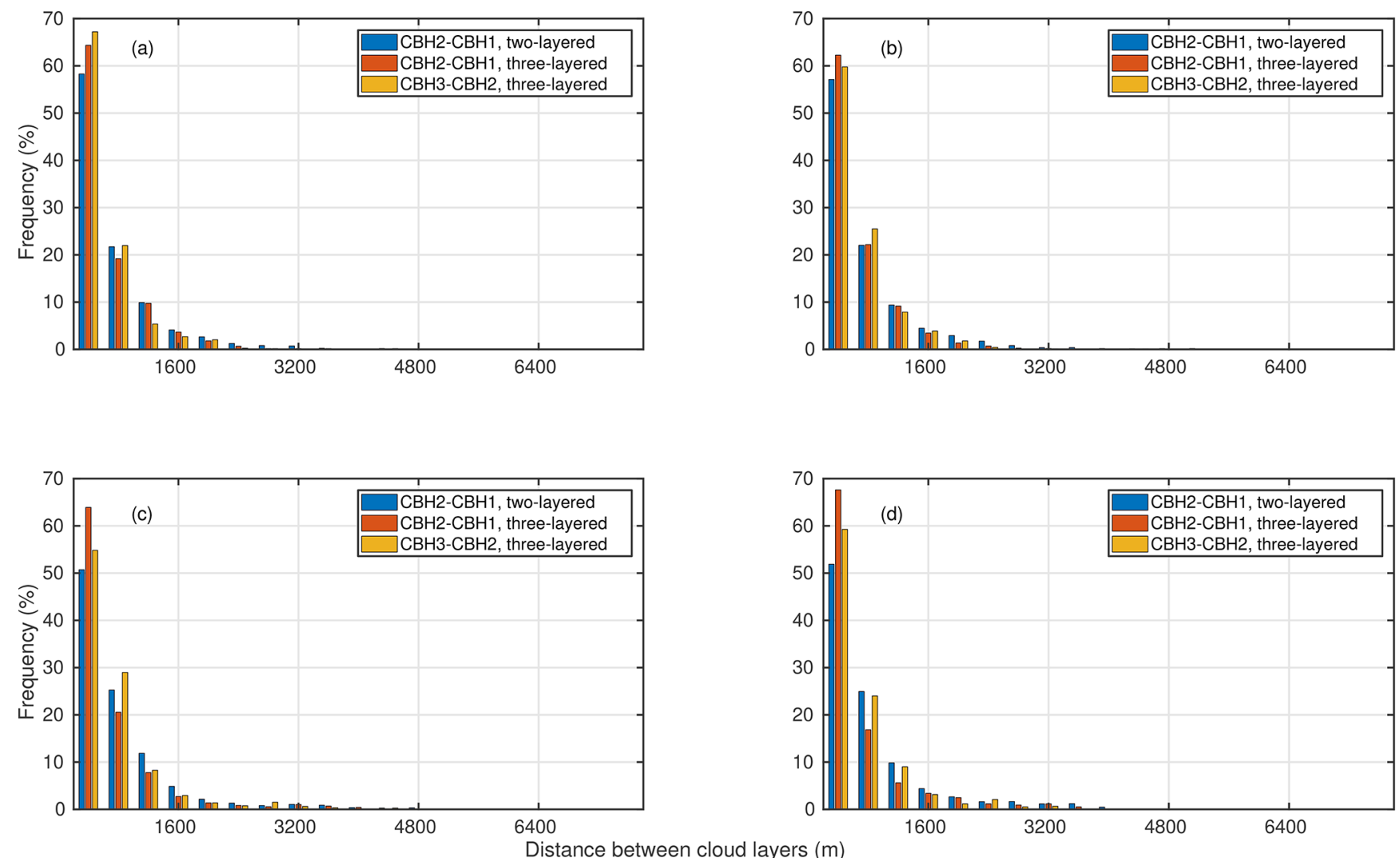

Figure B5. Distribution of the height difference between cloud layers. Blue represents the difference between the lowest and the second cloud layer in two-layered clouds, red similarly but in three-layered clouds and yellow represents the difference between the second and the third cloud layer. (a) Spring, (b) summer, (c) autumn and (d) winter. 


\section{B2 Cloud statistics using the new cloud algorithm}
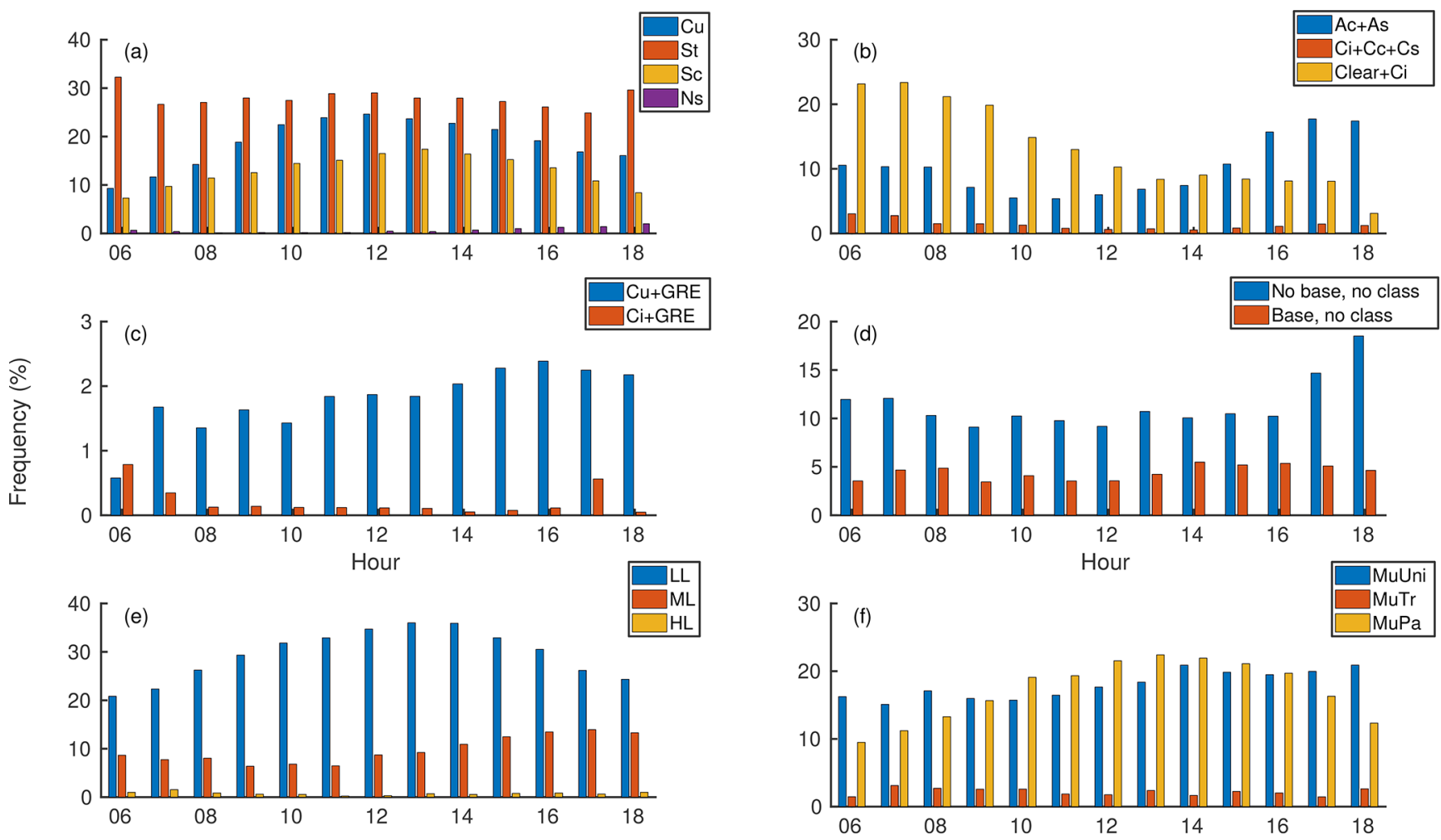

Figure B6. Diurnal variation of clouds types. (a) Low clouds, (b) middle- and high-level clouds, (c) height classes of multilayered clouds, (d) characteristic classes of multilayered clouds, (e) cumulus and cirrus clouds causing GRE and (f) cases when cloud class could not be determined in situations when the ceilometer did or did not detect a cloud base. The explanations of the abbreviations of the cloud classes are provided in Table 1. Notice the differences in $y$-axis scaling. 


\section{B3 Discussion}
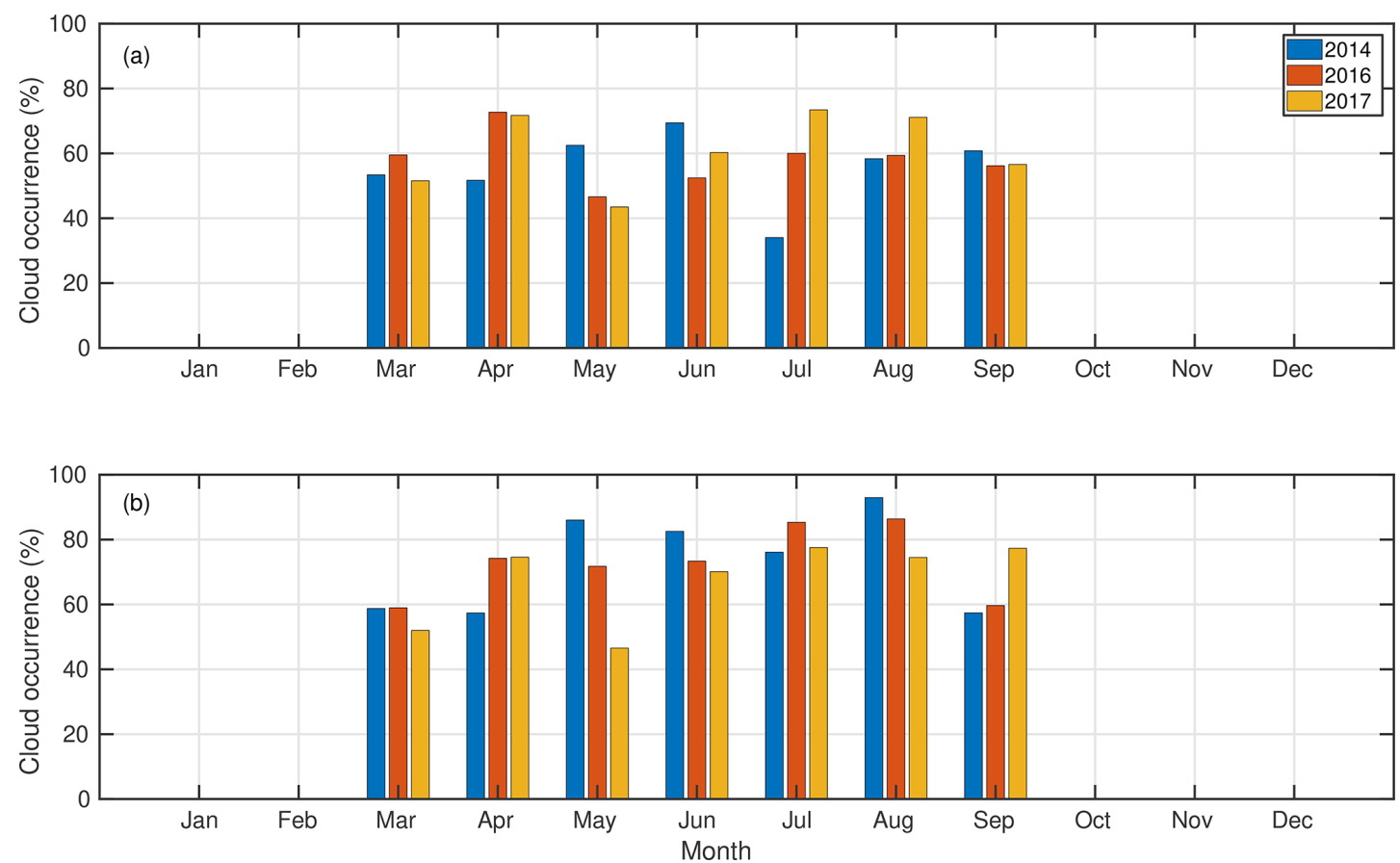

Figure B7. Monthly-average cloud occurrence observed in Hyytiälä based on (a) the ceilometer and (b) the pyranometer measurements. Daytime (09:00-15:00 LT) values from March to September when SZA was less than $70^{\circ}$ were used. The number of cloud observations was divided by the total number of data points in 1 month to obtain the cloud occurrence. The occurrence estimated from the ceilometer measurements (64\%) was lower compared to the occurrence estimated from the pyranometer data $(71 \%)$. 
Code and data availability. The used data measured at SMEAR II can be accessed with the Smart-SMEAR online tool (https://avaa.tdata.fi/web/smart/smear/download, SmartSMEAR, 2020; Junninen et al., 2009). AOD and precipitable water data were obtained from AERONET database and are available at https: //aeronet.gsfc.nasa.gov/cgi-bin/webtool_opera_v2_new?stage= $3 \&$ region $=$ Europe $\&$ state $=$ Finland $\&$ site $=$ Hyytiala $\&$ place $\_$code $=10$ (AERONET, 2020; Holben et al., 1998). Total-sky images are available at https://adc.arm.gov/discovery/\#v/results/s/fsite::tmp (ARM, 2020; Petäjä et al., 2016). The cloud classification produced in this study is available upon request from the first author at ilona.ylivinkka@helsinki.fi.

Author contributions. EE and MK developed the concept of the study. MP and MV initiated the data analysis and development of the algorithm. SK refined the parameter ranges of the algorithm using total-sky images and estimated the performance of the algorithm. IY performed the data analysis for the paper and wrote it. EE, DT, TP and VMK helped with the interpretation of the results. All authors gave critical feedback and helped with shaping the paper.

Competing interests. The authors declare that they have no conflict of interest.

Acknowledgements. The authors are grateful to the two referees who helped to improve the clarity of the paper. We thank Academy of Finland and ACTRIS infrastructure for the support. The results are part of a project (ATM-GTP/ERC) that has received funding from the European Research Council (ERC) under the European Union's Horizon 2020 research and innovation program.

Financial support. This research has been supported by the Academy of Finland Center of Excellence program (grant no. 307331), professor grant to Markku Kulmala (grant no. 302958) and a grant to Ditte Taipale (grant no. 307957); and the H2020 European Research Council (ATM-GTP, grant no. 742206).

Open access funding provided by Helsinki University Library.

Review statement. This paper was edited by Vassilis Amiridis and reviewed by two anonymous referees.

\section{References}

AERONET: AERONET Data Download Tool, available at: https://aeronet.gsfc.nasa.gov/cgi-bin/webtool_opera_v2_new? stage $=3 \&$ region $=$ Europe $\&$ state $=$ Finland $\&$ site $=$ Hyytiala $\&$ place code $=10$, last access: 21 October 2020.

Albrecht, B. A.: Aerosols, cloud microphysics, and fractional cloudiness, Science, 245, 1227-1230, 1989.

ARM: ARM Data search, available at: https://adc.arm.gov/ discovery/\#/results/site_code::tmp, last access: 21 October 2020.
Atkinson, R. and Arey, J.: Gas-phase tropospheric chemistry of biogenic volatile organic compounds: a review, Atmos. Environ., 37, 197-219, 2003.

Bankert, R. L. and Wade, R. H.: Optimization of an instance-based GOES cloud classification algorithm, J. Appl. Meteorol. Clim., 46, 36-49, 2007.

Bohren, C. F.: Multiple scattering of light and some of its observable consequences, Am. J. Phys., 55, 524-533, 1987.

Calbó, J. and Sabburg, J.: Feature extraction from whole-sky ground-based images for cloud-type recognition, J. Atmos. Ocean. Tech., 25, 3-14, 2008.

Calbó, J., González, J.-A., and Pagès, D.: A method for skycondition classification from ground-based solar radiation measurements, J. Appl. Meteorol., 40, 2193-2199, 2001.

Cayula, J.-F. and Cornillon, P.: Cloud detection from a sequence of SST images, Remote Sens. Environ., 55, 80-88, 1996.

Costa-Surós, M., Calbó, J., González, J., and Martin-Vide, J.: Behavior of cloud base height from ceilometer measurements, Atmos. Res., 127, 64-76, 2013.

Dada, L., Paasonen, P., Nieminen, T., Buenrostro Mazon, S., Kontkanen, J., Peräkylä, O., Lehtipalo, K., Hussein, T., Petäjä, T., Kerminen, V.-M., Bäck, J., and Kulmala, M.: Long-term analysis of clear-sky new particle formation events and nonevents in Hyytiälä, Atmos. Chem. Phys., 17, 6227-6241, https://doi.org/10.5194/acp-17-6227-2017, 2017.

Dada, L., Chellapermal, R., Buenrostro Mazon, S., Paasonen, P., Lampilahti, J., Manninen, H. E., Junninen, H., Petäjä, T., Kerminen, V.-M., and Kulmala, M.: Refined classification and characterization of atmospheric new-particle formation events using air ions, Atmos. Chem. Phys., 18, 17883-17893, https://doi.org/10.5194/acp-18-17883-2018, 2018.

Donahue, N. M., Ortega, I. K., Chuang, W., Riipinen, I., Riccobono, F., Schobesberger, S., Dommen, J., Baltensperger, U., Kulmala, M., Worsnop, D. R., and Vehkamäki, H.: How do organic vapors contribute to new-particle formation?, Faraday Discuss., 165, 91-104, 2013.

Duchon, C. E. and O'Malley, M. S.: Estimating cloud type from pyranometer observations, J. Appl. Meteorol., 38, 132-141, 1999.

Eastman, R. and Warren, S. G.: Diurnal cycles of cumulus, cumulonimbus, stratus, stratocumulus, and fog from surface observations over land and ocean, J. Climate, 27, 2386-2404, 2014.

Ehn, M., Thornton, J. A., Kleist, E., Sipilä, M., Junninen, H., Pullinen, I., Springer, M., Rubach, F., Tillmann, R., Lee, B., LopezHilfiker, F., Andres, S., Acir, I.-H., Rissanen, M., Jokinen, T., Schobesberger, S., Kangasluoma, J., Kontkanen, J., Nieminen, T., Kurtén, T., Nielsen, L. B., Jørgensen, S., Kjaergaard, H. G., Canagaratna, M., Dal Maso, M., Berndt, T., Petäjä, T., Wahner, A., Kerminen, V.-M., Kulmala, M., Worsnop, D. R., Wildt, J., and Mentel T. F.: A large source of low-volatility secondary organic aerosol, Nature, 506, 476-479, 2014.

Ezhova, E., Ylivinkka, I., Kuusk, J., Komsaare, K., Vana, M., Krasnova, A., Noe, S., Arshinov, M., Belan, B., Park, S.-B., Lavrič, J. V., Heimann, M., Petäjä, T., Vesala, T., Mammarella, I., Kolari, P., Bäck, J., Rannik, Ü., Kerminen, V.-M., and Kulmala, M.: Direct effect of aerosols on solar radiation and gross primary production in boreal and hemiboreal forests, Atmos. Chem. Phys., 18, 17863-17881, https://doi.org/10.5194/acp-18-178632018, 2018. 
Gryspeerdt, E., Stier, P., and Partridge, D. G.: Satellite observations of cloud regime development: the role of aerosol processes, Atmos. Chem. Phys., 14, 1141-1158, https://doi.org/10.5194/acp14-1141-2014, 2014.

Gu, L., Fuentes, J. D., Shugart, H. H., Staebler, R. M., and Black, T. A.: Responses of net ecosystem exchanges of carbon dioxide to changes in cloudiness: Results from two North American deciduous forests, J. Geophys. Res.-Atmos., 104, 31421-31434, 1999.

Gu, L., Baldocchi, D., Verma, S. B., Black, T., Vesala, T., Falge, E. M., and Dowty, P. R.: Advantages of diffuse radiation for terrestrial ecosystem productivity, J. Geophys. Res.-Atmos., 107, ACL 2-1-ACL 2-23, https://doi.org/10.1029/2001JD001242, 2002.

Hahn, C. J. and Warren, S. G.: A gridded climatology of clouds over land (1971-96) and ocean (1954-97) from surface observations worldwide, Oak Ridge National Laboratory, Carbon Dioxide Information Analysis Center, Oak Ridge, Tennessee, USA, 2007.

Hallquist, M., Wenger, J. C., Baltensperger, U., Rudich, Y., Simpson, D., Claeys, M., Dommen, J., Donahue, N. M., George, C., Goldstein, A. H., Hamilton, J. F., Herrmann, H., Hoffmann, T., Iinuma, Y., Jang, M., Jenkin, M. E., Jimenez, J. L., Kiendler-Scharr, A., Maenhaut, W., McFiggans, G., Mentel, Th. F., Monod, A., Prévôt, A. S. H., Seinfeld, J. H., Surratt, J. D., Szmigielski, R., and Wildt, J.: The formation, properties and impact of secondary organic aerosol: current and emerging issues, Atmos. Chem. Phys., 9, 5155-5236, https://doi.org/10.5194/acp9-5155-2009, 2009.

Haralick, R. M., Shanmugam, K., and Dinstein, I.: Textural features for image classification, IEEE T. Syst. Man Cyb., 3, 610-621, 1973.

Hari, P. and Kulmala, M.: Station for Measuring EcosystemAtmosphere Relations (SMEAR II), Boreal Environ. Res., 10, 315-322, 2005.

Heinle, A., Macke, A., and Srivastav, A.: Automatic cloud classification of whole sky images, Atmos. Meas. Tech., 3, 557-567, https://doi.org/10.5194/amt-3-557-2010, 2010.

Hellén, H., Praplan, A. P., Tykkä, T., Ylivinkka, I., Vakkari, V., Bäck, J., Petäjä, T., Kulmala, M., and Hakola, H.: Longterm measurements of volatile organic compounds highlight the importance of sesquiterpenes for the atmospheric chemistry of a boreal forest, Atmos. Chem. Phys., 18, 13839-13863, https://doi.org/10.5194/acp-18-13839-2018, 2018.

Holben, B. N., Eck, T. F., Slutsker, I., Tanre, D., Buis, J., Setzer, A., Vermote, E., Reagan, J. A., Kaufman, Y., Nakajima, T., Lavenu, F., Jankowiak, I., and Smirnov, A.: AERONET-A federated instrument network and data archive for aerosol characterization, Remote Sens. Environ., 66, 1-16, 1998.

Houze Jr., R. A.: Cloud dynamics, 2nd edition, Academic press, Oxford, UK, ISBN 978-0-12-374266-7, 2014.

Hussein, T., Junninen, H., Tunved, P., Kristensson, A., Dal Maso, M., Riipinen, I., Aalto, P. P., Hansson, H.-C., Swietlicki, E., and Kulmala, M.: Time span and spatial scale of regional new particle formation events over Finland and Southern Sweden, Atmos. Chem. Phys., 9, 4699-4716, https://doi.org/10.5194/acp-9-46992009, 2009.

Illingworth, A., Hogan, R., O'connor, E., Bouniol, D., Brooks, M., Delanoë, J., Donovan, D., Eastment, J., Gaussiat, N., Goddard, J., Haeffelin, M., Klein Baltink, H., Krasnov, O. A., Pelon, J.,
Piriou, J.-M., Protat A., Russchenberg, H. W. J., Seifert, A., Tompkins, A. M., van Zadelhoff, G.-J., Vinit, F., Willén, U., Wilson, D. R., and Wrench, C. L.: Cloudnet: Continuous evaluation of cloud profiles in seven operational models using ground-based observations, B. Am. Meteorol. Soc., 88, 883-898, 2007.

Ineichen, P.: A broadband simplified version of the Solis clear sky model, Sol. Energy, 82, 758-762, 2008.

IPCC: Climate Change 2013: The Physical Science Basis. Contribution of Working Group I to the Fifth Assessment Report of the Intergovernmental Panel on Climate Change, edited by: Stocker, T. F., Qin, D., Plattner, G.-K., Tignor, M., Allen, S. K., Boschung, J., Nauels, A., Xia, Y., Bex, V., and Midgley, P. M., Cambridge University Press, Cambridge, UK and New York, NY, USA, 2013.

Jokinen, T., Kontkanen, J., Lehtipalo, K., Manninen, H. E., Aalto, J., Porcar-Castell, A., Garmash, O., Nieminen, T., Ehn, M., Kangasluoma, J., Junninen, H., Levula, J., Duplissy, J., Ahonen L. R., Rantala, P., Heikkinen, L., Yan, C., Sipilä, M., Worsnop, D. R., Bäck, J., Petäjä, T., Kerminen, V.-M., and Kulmala, M.: Solar eclipse demonstrating the importance of photochemistry in new particle formation, Scientific reports, 7, 45707, https://doi.org/10.1038/srep45707, 2017.

Joro, S., Hyvärinen, O., and Kotro, J.: Comparison of satellite cloud masks with ceilometer sky conditions in southern Finland, J. Appl. Meteorol. Clim., 49, 2508-2526, 2010.

Junninen, H., Lauri, A., Keronen, P., Aalto, P., Hiltunen, V., Hari, P., and Kulmala, M.: Smart-SMEAR: on-line data exploration and visualization tool for SMEAR stations, Boreal Environ. Res., 14, 447-457, 2009.

Kalb, C. P., Dean, A., Peppler, R., and Sonntag, K.: Intercomparison of cloud base height at the ARM Southern Great plains site, in: Proceedings of the 14th Atmospheric Radiation Measurement (ARM) Science Team Meeting, 22-26 March 2004, Albuquerque, New Mexico, USA, 2004.

Karlsson, K.-G.: A 10 year cloud climatology over Scandinavia derived from NOAA advanced very high resolution radiometer imagery, Int. J. Climatol., 23, 1023-1044, 2003.

Kasten, F. and Czeplak, G.: Solar and terrestrial radiation dependent on the amount and type of cloud, Sol. Energy, 24, 177-189, 1980.

Kegelmeyer Jr., W.: Extraction of cloud statistics from whole sky imaging cameras, Tech. rep., Sandia National Labs., Livermore, CA, USA, 1994.

Kerminen, V.-M., Paramonov, M., Anttila, T., Riipinen, I., Fountoukis, C., Korhonen, H., Asmi, E., Laakso, L., Lihavainen, H., Swietlicki, E., Svenningsson, B., Asmi, A., Pandis, S. N., Kulmala, M., and Petäjä, T.: Cloud condensation nuclei production associated with atmospheric nucleation: a synthesis based on existing literature and new results, Atmos. Chem. Phys., 12, 1203712059, https://doi.org/10.5194/acp-12-12037-2012, 2012.

Kivalov, S. N.: Whole-Canopy Net Ecosystem Exchange and Water Use Efficiency in an Intermittent-Light Environment - Dynamic Approach, State University of New York at Albany, USA, 2018.

Kulmala, M., Riipinen, I., Nieminen, T., Hulkkonen, M., Sogacheva, L., Manninen, H. E., Paasonen, P., Petäjä, T., Dal Maso, M., Aalto, P. P., Viljanen, A., Usoskin, I., Vainio, R., Mirme, S., Mirme, A., Minikin, A., Petzold, A., Hõrrak, U., Plaß-Dülmer, C., Birmili, W., and Kerminen, V.-M.: Atmospheric data over a solar cycle: no connection between galactic cosmic rays and 
new particle formation, Atmos. Chem. Phys., 10, 1885-1898, https://doi.org/10.5194/acp-10-1885-2010, 2010.

Kulmala, M., Nieminen, T., Nikandrova, A., Lehtipalo, K., Manninen, H. E., Kajos, M. K., Kolari, P., Lauri, A., Petäjä, T., Krejci, R., Hansson, H.-C., Swietlicki, E., Lindroth, A., Christensen, T. R., Arneth, A., Hari, P., Bäck, J., Vesala, T., and Kerminen, V.M.: $\mathrm{CO}_{2}$-induced terrestrial climate feedback mechanism: From carbon sink to aerosol source and back, Boreal Environ. Res., 19 (suppl. B), 122-131, 2014a.

Kulmala, M., Petäjä, T., Ehn, M., Thornton, J., Sipilä, M., Worsnop, D., and Kerminen, V.-M.: Chemistry of atmospheric nucleation: on the recent advances on precursor characterization and atmospheric cluster composition in connection with atmospheric new particle formation, Annu. Rev. Phys. Chem., 65, 21-37, $2014 \mathrm{~b}$.

Lampilahti, J., Manninen, H. E., Leino, K., Väänänen, R., Manninen, A., Buenrostro Mazon, S., Nieminen, T., Leskinen, M., Enroth, J., Bister, M., Zilitinkevich, S., Kangasluoma, J., Järvinen, H., Kerminen, V.-M., Petäjä, T., and Kulmala, M.: Roll vortices induce new particle formation bursts in the planetary boundary layer, Atmos. Chem. Phys. Discuss., https://doi.org/10.5194/acp2019-1013, in review, 2020.

Leino, K., Lampilahti, J., Poutanen, P., Väänänen, R., Manninen, A., Buenrostro Mazon, S., Dada, L., Franck, A., Wimmer, D., Aalto, P. P., Ahonen, L. R., Enroth, J., Kangasluoma, J., Keronen, P., Korhonen, F., Laakso, H., Matilainen, T., Siivola, E., Manninen, H. E., Lehtipalo, K., Kerminen, V.-M., Petäjä, T., and Kulmala, M.: Vertical profiles of sub-3 nm particles over the boreal forest, Atmos. Chem. Phys., 19, 4127-4138, https://doi.org/10.5194/acp-19-4127-2019, 2019.

Li, J., Huang, J., Stamnes, K., Wang, T., Lv, Q., and Jin, H.: A global survey of cloud overlap based on CALIPSO and CloudSat measurements, Atmos. Chem. Phys., 15, 519-536, https://doi.org/10.5194/acp-15-519-2015, 2015.

Loeb, N. G., Wielicki, B. A., Doelling, D. R., Smith, G. L., Keyes, D. F., Kato, S., Manalo-Smith, N., and Wong, T.: Toward optimal closure of the Earth's top-of-atmosphere radiation budget, J. Climate, 22, 748-766, 2009.

Lohmann, U., Lüönd, F., and Mahrt, F.: An introduction to clouds: From the microscale to climate, Cambridge University Press, Cambridge, UK, 2016.

Long, C. N. and Ackerman, T. P.: Identification of clear skies from broadband pyranometer measurements and calculation of downwelling shortwave cloud effects, J. Geophys. Res.-Atmos., 105, 15609-15626, 2000.

Mazzoni, D., Garay, M. J., Davies, R., and Nelson, D.: An operational MISR pixel classifier using support vector machines, Remote Sens. Environ., 107, 149-158, 2007.

Mogensen, D., Smolander, S., Sogachev, A., Zhou, L., Sinha, V., Guenther, A., Williams, J., Nieminen, T., Kajos, M. K., Rinne, J., Kulmala, M., and Boy, M.: Modelling atmospheric OH-reactivity in a boreal forest ecosystem, Atmos. Chem. Phys., 11, 97099719, https://doi.org/10.5194/acp-11-9709-2011, 2011.

Mogensen, D., Gierens, R., Crowley, J. N., Keronen, P., Smolander, S., Sogachev, A., Nölscher, A. C., Zhou, L., Kulmala, M., Tang, M. J., Williams, J., and Boy, M.: Simulations of atmospheric $\mathrm{OH}$, $\mathrm{O}_{3}$ and $\mathrm{NO}_{3}$ reactivities within and above the boreal forest, Atmos. Chem. Phys., 15, 3909-3932, https://doi.org/10.5194/acp15-3909-2015, 2015.
Mukherjee, D. P. and Acton, S. T.: Cloud tracking by scale space classification, IEEE T. Geosci. Remote, 40, 405-415, 2002.

Niple, E. R. and Scott, H. E.: Biogenic Aerosols - Effects on Climate and Clouds. Cloud Optical Depth (COD) Sensor Three-Waveband Spectrally-Agile Technique (TWST) Field Campaign Report, Tech. rep., United States, https://doi.org/10.2172/1248494, 2016.

Paasonen, P., Asmi, A., Petäjä, T., Kajos, M. K., Äijälä, M., Junninen, H., Holst, T., Abbatt, J. P., Arneth, A., Birmili, W., Denier van der Gon, H., Hamed, A., Hoffer, A., Laakso, L., Laaksonen, A., Leaitch, W. R., Plass-Dülmer, C., Pryor, S. C., Räisänen, P., Swietlicki, E., Wiedensohler, A., Worsnop, D. R., Kerminen, V.-M., and Kulmala, M.: Warming-induced increase in aerosol number concentration likely to moderate climate change, Nat. Geosci., 6, 438-442, 2013.

Page, J.: The role of solar-radiation climatology in the design of photovoltaic systems, in: Practical Handbook of Photovoltaics, Elsevier, Oxford, UK, 573-643, 2012.

Pecenak, Z. K., Mejia, F. A., Kurtz, B., Evan, A., and Kleissl, J.: Simulating irradiance enhancement dependence on cloud optical depth and solar zenith angle, Sol. Energy, 136, 675-681, 2016.

Perry, K. D. and Hobbs, P. V.: Further evidence for particle nucleation in clear air adjacent to marine cumulus clouds, J. Geophys. Res.-Atmos., 99, 22803-22818, 1994.

Petäjä, T., O’Connor, E. J., Moisseev, D., Sinclair, V. A., Manninen, A. J., Väänänen, R., von Lerber, A., Thornton, J. A., Nicoll, K., Petersen, W., Chandrasekar, V., Smith, J. N., Winkler, P. M., Krüger, O., Hakola, H., Timonen, H., Brus, D., Laurila, T., Asmi, E., Riekkola, M.-L., Mona, L., Massoli, P., Engelmann, R., Komppula, M., Wang, J., Kuang, C., Bäck, J., Virtanen, A., Levula, J., Ritsche, M., and Hickmon, N.: BAECC: A field campaign to elucidate the impact of biogenic aerosols on clouds and climate, B. Am. Meteorol. Soc., 97, 1909-1928, 2016.

Pipatti, R., Esala, M., Jääskeläinen S., Kolttola, L. Kuusisto, E., Luhtala, S., Mikkonen, I., Niinioja, M., Niinistö, S., Nummelin, M., Perälä, M., Pingoud, K., Seitsonen, H., Stenborg, M., Tervo, M., Tolonen-Kivimäki, O., Tuomenvirta, H., Uusivuori, J., Raittinen, L., Skoglund, K., and Kimpanpää, M.: Finland's Fifth National Communication under the United Nations Framework Convention on Climate Change, Ministry of the Environment and Statistics Finland, edited by: Kimpanpää, M., Helsinki, Finland, ISBN 978-952-244-184-3, 280 pp, 2009.

Rannik, Ü., Launiainen, S., Pumpanen, J., Kulmala, L., Kolari, P., Vesala, T., Korhonen, J. F., and Hari, P.: Environmental factors, in: Physical and Physiological Forest Ecology, Springer, Dordrecht, the Netherlands, 27-42, 2013.

Ricciardelli, E., Romano, F., and Cuomo, V.: Physical and statistical approaches for cloud identification using meteosat second generation-spinning enhanced visible and infrared imager data, Remote Sens. Environ., 112, 2741-2760, 2008.

Riccobono, F., Schobesberger, S., Scott, C. E., Dommen, J., Ortega, I. K., Rondo, L., Almeida, J., Amorim, A., Bianchi, F., Breitenlechner, M., David, A., Downard, A., Dunne, E. M., Duplissy, J., Ehrhart, S., Flagan, R.C., Franchin, A., Hansel, A., Junninen, H., Kajos, M., Keskinen, H., Kupc, A., Kürten, A., Kvashin, A. N., Laaksonen, A., Lehtipalo, K., Makhmutov, V., Mathot, S., Nieminen, T., Onnela, A., Petäjä, T., Praplan, A. P., Santos, F. D., Schallhart, S., Seinfeld, J. H., Sipilä, M., Spracklen, D. V., Stozhkov, Y., Stratmann, F., Tomé, A., Tsagkogeorgas, G., 
Vaattovaara, P., Viisanen, Y., Vrtala, A., Wagner, P. E., Weingartner, E., Wex, H., Wimmer, D., Carslaw, K. S., Curtius, J., Donahue, N. M., Kirkby, J., Kulmala, M., Worsnop, D. R., and Baltensperger, U.: Oxidation products of biogenic emissions contribute to nucleation of atmospheric particles, Science, 344, 717 721, 2014

Riipinen, I., Yli-Juuti, T., Pierce, J. R., Petäjä, T., Worsnop, D. R., Kulmala, M., and Donahue, N. M.: The contribution of organics to atmospheric nanoparticle growth, Nat. Geosci., 5, 453-458, 2012.

Rodriguez, D.: On the comparability of cloud fractions derived from whole sky imager and ceilometer data, Tech. rep., Lawrence Livermore National Lab., Livermore, CA, USA, 1998.

Rodts, S. M. A., Duynkerke, P. G., and Jonker, H. J. J.: Size Distributions and Dynamical Properties of Shallow Cumulus Clouds from Aircraft Observations and Satellite Data, J. Atmos. Sci., 60, 1895-1912, https://doi.org/10.1175/15200469(2003)060<1895:SDADPO>2.0.CO;2, 2003.

Rosenfeld, D., Andreae, M. O., Asmi, A., Chin, M., de Leeuw, G., Donovan, D. P., Kahn, R., Kinne, S., Kivekäs, N., Kulmala, M., Lau, W., Schmidt, K. S., Suni, T., Wagner, T., Wild, M., and Quaas, J.: Global observations of aerosol-cloud-precipitationclimate interactions, Rev. Geophys., 52, 750-808, 2014.

Rossow, W. B. and Zhang, Y.: Evaluation of a statistical model of cloud vertical structure using combined CloudSat and CALIPSO cloud layer profiles, J. Climate, 23, 6641-6653, 2010.

Rossow, W. B., Zhang, Y., and Wang, J.: A statistical model of cloud vertical structure based on reconciling cloud layer amounts inferred from satellites and radiosonde humidity profiles, J. Climate, 18, 3587-3605, 2005.

Schneider, S. H. and Dennett, R. D.: Climatic barriers to long-term energy growth, Ambio, 4, 65-74, 1975.

Schobesberger, S., Junninen, H., Bianchi, F., Lönn, G., Ehn, M., Lehtipalo, K., Dommen, J., Ehrhart, S., Ortega, I. K., Franchin, A., Nieminen, T., Riccobono, F., Hutterli, M., Duplissy, J., Almeida, J., Amorim, A., Breitenlechner, M., Downard, A. J., Dunne, E. A., Flagan, R. C., Kajos, M., Keskinen, H., Kirkby, J., Kupc, A., Kürten, A., Kurtén, T., Laaksonen, A., Mathot, S., Onnela, A., Praplan, A. P., Rondo, L., Santos, F. D., Schallhart, S, Schnitzhofer, R., Sipilä, M., Tomé, A., Tsagkogeorgas, G., Vehkamäki, H., Wimmer, D., Baltensperger, U., Carslaw, K. S., Curtius, J., Hansel, A., Petäjä, T., Kulmala, M., Donahue, N. M., and Worsnop, D. R.: Molecular understanding of atmospheric particle formation from sulfuric acid and large oxidized organic molecules, P. Natl. Acad. Sci. USA, 110, 17223-17228, 2013.

Scott, C., Arnold, S., Monks, S., Asmi, A., Paasonen, P., and Spracklen, D.: Substantial large-scale feedbacks between natural aerosols and climate, Nat. Geosci., 11, 44-48, 2018.
Sena, E. T., McComiskey, A., and Feingold, G.: A longterm study of aerosol-cloud interactions and their radiative effect at the Southern Great Plains using groundbased measurements, Atmos. Chem. Phys., 16, 11301-11318, https://doi.org/10.5194/acp-16-11301-2016, 2016.

Sinha, A. and Shine, K.: Simulated sensitivity of the earth's radiation budget to changes in cloud properties, Q. J. Roy. Meteorol. Soc., 121, 797-819, 1995.

SmartSMEAR: SmartSMEAR Download tool, available at: https:// avaa.tdata.fi/web/smart/smear/download, last access: 21 October 2020.

Sporre, M. K., Blichner, S. M., Karset, I. H. H., Makkonen, R., and Berntsen, T. K.: BVOC-aerosol-climate feedbacks investigated using NorESM, Atmos. Chem. Phys., 19, 4763-4782, https://doi.org/10.5194/acp-19-4763-2019, 2019.

Stull, R. B.: Meteorology for scientists and engineers, 2nd edn, Brooks/Cole, Pacific Grove, CA, USA, 2000.

Tapakis, R. and Charalambides, A.: Equipment and methodologies for cloud detection and classification: A review, Sol. Energy, 95, 392-430, 2013.

Twohy, C. H., Clement, C. F., Gandrud, B. W., Weinheimer, A. J., Campos, T. L., Baumgardner, D., Brune, W. H., Faloona, I., Sachse, G. W., Vay, S. A., and Tan, D.: Deep convection as a source of new particles in the midlatitude upper troposphere, J. Geophys. Res.-Atmos., 107, AAC 6-1-AAC6-10, https://doi.org/10.1029/2001JD000323, 2002.

Twomey, S.: The influence of pollution on the shortwave albedo of clouds, J. Atmos. Sci., 34, 1149-1152, 1977.

Waddicor, D. A., Vaughan, G., Choularton, T. W., Bower, K. N., Coe, H., Gallagher, M., Williams, P. I., Flynn, M., Volz-Thomas, A., Pätz, H.-W., Isaac, P., Hacker, J., Arnold, F., Schlager, H., and Whiteway, J. A.: Aerosol observations and growth rates downwind of the anvil of a deep tropical thunderstorm, Atmos. Chem. Phys., 12, 6157-6172, https://doi.org/10.5194/acp12-6157-2012, 2012.

Wang, J. and Rossow, W. B.: Determination of cloud vertical structure from upper-air observations, J. Appl. Meteorol., 34, 2243 2258, 1995.

Wang, J., Rossow, W. B., Uttal, T., and Rozendaal, M.: Variability of cloud vertical structure during ASTEX observed from a combination of rawinsonde, radar, ceilometer, and satellite, Mon. Weather Rev., 127, 2484-2502, 1999.

Wang, J., Rossow, W. B., and Zhang, Y.: Cloud vertical structure and its variations from a 20 -yr global rawinsonde dataset, J. Climate, 13, 3041-3056, 2000.

Wang, Z. and Sassen, K.: Cloud type and macrophysical property retrieval using multiple remote sensors, J. Appl. Meteorol., 40, 1665-1682, 2001. 